\title{
Cuprous oxide on charcoal-catalyzed ligand-free synthesis of 1,4-disubstituted 1,2,3-triazoles via click chemistry
}

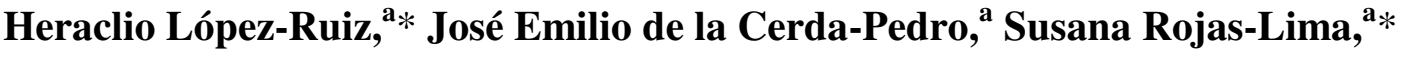 Imelda Pérez-Pérez, ${ }^{a}$ Brianda Viridiana Rodríguez-Sánchez, ${ }^{a}$ Rosa Santillan, and Oscar Coreño ${ }^{c}$}

${ }^{a}$ Área Académica de Química, Universidad Autónoma del Estado de Hidalgo, Carretera Pachuca-Tulancingo Km 4.5, Ciudad Universitaria, 42184 Mineral de la Reforma, Hidalgo, México

${ }^{b}$ Departamento de Química, Centro de Investigación y de Estudios Avanzados del Instituto Politécnico Nacional, Apto. Postal 14-740, 07000 México D.F., México

${ }^{c}$ Departamento de Ingeniería Civil, Universidad de Guanajuato, Juárez 77, Col. Centro, 36000 Guanajuato, México

E-mail: heraclio@uaeh.edu.mx

\begin{abstract}
Cuprous oxide on charcoal $\left(\mathrm{Cu}_{2} \mathrm{O} / \mathrm{C}\right)$, the preparation of which is described for the first time, catalyzes the formation of 1,4-disubstituted 1,2,3-triazoles from organic azides and terminal alkynes in good to excellent yields (69-94\%). These disubstituted triazoles can be equally efficiently generated in a one-pot process from alkyl bromides, sodium azide, and terminal acetylenes in $50 \%$ aqueous isopropanol containing a suspension of the catalyst. This obviates the necessity to isolate potentially explosive organic azides.
\end{abstract}

Keywords: 1,3-Dipolar cycloaddition, click chemistry, $\mathrm{Cu}_{2} \mathrm{O} / \mathrm{C}$, triazoles

\section{Introduction}

Recent advances in the Huisgen 1,3-dipolar cycloaddition reaction have led to a renewed interest in its applications to the synthesis of 1,2,3-triazoles. ${ }^{1}$ Small molecules containing the triazole functionality have been shown to exhibit a range of biological functions, including antitumor, antibacterial, antiparasitic and antiviral activity (Figure 1$)^{2}$ 


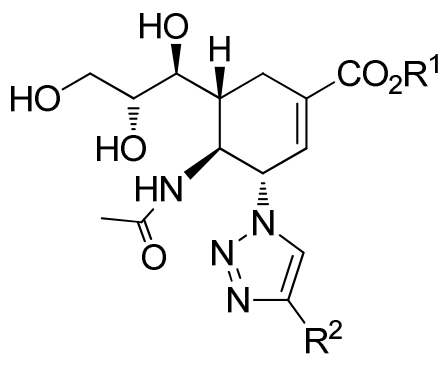

A (Zaminivir analogue $)^{2 b}$

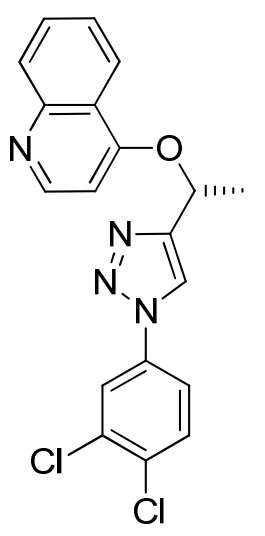

B (antiparasitic) ${ }^{2 d}$<smiles>O=C1C(Nc2cccc(O)c2)=C(n2nnc3ccccc32)C(=O)c2ccccc21</smiles>

C (antiviral) ${ }^{2 f}$

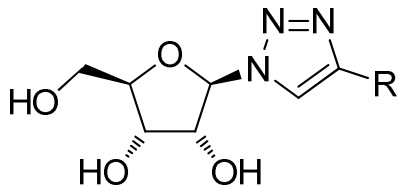

D (Ribavirin analogue) $)^{2 \mathrm{~g}}$

Figure 1. Representative examples of biologically active 1,2,3-triazoles.

Historically, 1,2,3-triazoles have been prepared via the Huisgen 1,3-dipolar cycloaddition reaction of azides and alkynes. ${ }^{1 \mathrm{a}, 3}$ This reaction sometimes requires relatively high temperatures and long reaction times. The main disadvantage of this methodology is that regioisomeric mixtures of the 1,4- and 1,5-disubstituted 1,2,3-triazoles are often formed. Recently, Fokin and coworkers developed new methodology for the preparation of 1,5-dialkyl 1,2,3-triazoles in high yields from aryl azides and terminal alkynes in the presence of catalytic tetramethylammonium hydroxide or $\mathrm{Cp} * \mathrm{RuCl}\left(\mathrm{PPh}_{3}\right)_{2}{ }^{4}$ In addition, Sharpless ${ }^{1 \mathrm{c}}$ and Meldal ${ }^{\text {le }}$ have found that catalytic copper(I) dramatically accelerates the reaction resulting in the highly regioselective formation of 1,4-disubstituted triazoles. This powerful, highly reliable, and selective reaction meets the set of stringent criteria required in click chemistry as defined by Sharpless et al. ${ }^{1 \mathrm{~b}}$ Thus, the copper(I)catalysed process is the preferred methodology for effecting this reaction (See Scheme 1). The sources of copper(I) include: a) copper(I) salts, normally in the presence of a base and/or a ligand, b) in-situ reduction of copper(II) salts (e.g., copper sulfate with sodium ascorbate) and c) disproportionation of copper(0) and copper(II), generally limited to special applications. ${ }^{5}$ For instance, reactions performed in some of the commonly used solvents (e.g. water-alcohol solvent mixtures) can be problematic, especially for insoluble reagents or very soluble products, thus reducing the application scope. Another aspect to consider is the reaction time, which, in general, is relatively long, requiring 12-24 h for completion. The addition of some copper complexes ${ }^{6}$ or ligands 5,7 was found to enhance the reaction rate. New and interesting advances in the title reaction involve heterogeneous catalysis. Thus copper(I) on charcoal, in the presence of triethylamine, was shown to be an efficient heterogeneous catalyst for the title reaction, the reaction times being reduced to $10-120 \mathrm{~min}^{8}{ }^{8} \mathrm{Copper}(\mathrm{I})$ on zeolite was also recently found to catalyze the cycloaddition reaction from halides or tosylates, sodium azide, and alkynes. ${ }^{9}$ 


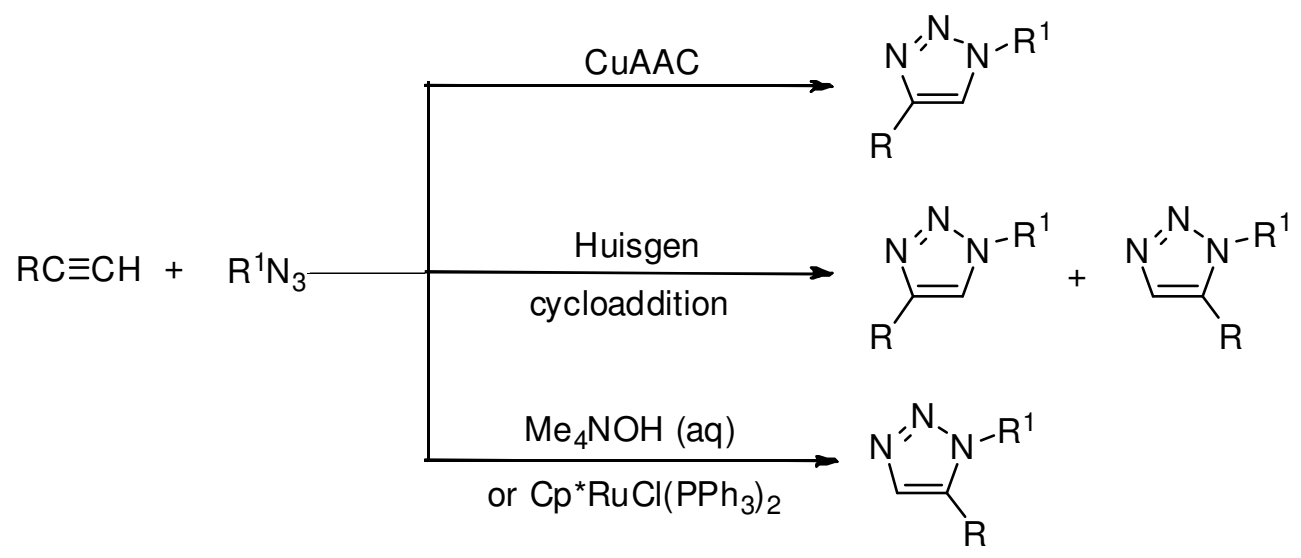

\section{Scheme 1}

Recently, increasing attention has been devoted to the use of copper nanoparticles (CuNPs), as substitutes for bulk copper metal, in order to reduce both the catalyst loading and the reaction time. ${ }^{10}$ Also the use of CuNPs has shown a general beneficial effect in the cycloaddition of alkynes and azides. Furthermore, easy-to-prepare and versatile heterogeneous copper catalysts that can efficiently promote the multicomponent 1,3-dipolar cycloaddition of organic azides and alkynes in water are welcome. Herein we describe the virtues of $\mathrm{Cu}_{2} \mathrm{O}$ on charcoal $\left(\mathrm{Cu}_{2} \mathrm{O} / \mathrm{C}\right)$ as a simple, inexpensive, general, and efficient heterogeneous catalyst for use in click chemistry.

\section{Results and Discussion}

\section{(a) Preparation of catalyst}

The copper catalyst immobilized on charcoal (Aldrich, Graphite 99.999\%, 325 mesh) was readily prepared in a two-step procedure. 1) Preparation of graphite. A high energy mill Spex 8000D, D2 tool steel and hardened steel balls were used. 50 balls of $1.04 \mathrm{~g}$ each, and $1.0 \mathrm{~g}$ of graphite $(99.999 \%, 325$ mesh) were introduced into the vial. Graphite was milled for 40 minutes under a static air atmosphere. 2) Impregnation of charcoal with $\mathrm{Cu}_{2} \mathrm{O}$ particles was done using $\mathrm{CuSO}_{4} \cdot 5 \mathrm{H}_{2} \mathrm{O}$ as the copper source. $\mathrm{CuSO}_{4} \cdot 5 \mathrm{H}_{2} \mathrm{O}(0.3062 \mathrm{~g})$ was dissolved in $5.68 \mathrm{~mL}$ of deionized water and $1.0 \mathrm{~g}$ of milled graphite was added to this solution. The volumetric flask (50 $\mathrm{mL}$ ) containing this mixture was placed in an ultrasonic bath for $1 \mathrm{~h}$. Finally, the resulting suspension was filtered and dried in an oven for $4 \mathrm{~h}$ at $110^{\circ} \mathrm{C}$, to obtain nanoparticle-size $\mathrm{Cu}_{2} \mathrm{O} / \mathrm{C} .{ }^{11}$ The cuprous oxide on charcoal catalyst was characterized by its $\mathrm{X}$-ray diffraction pattern (XRD). The copper content in the catalyst $(0.89 \mathrm{wt} \%)$, was determined by flame atomic absorption spectrophotometry (in 2\% nitric acid). Analysis by SEM images revealed the presence of agglomerates of around up to $5 \mu \mathrm{m}$, Figure 2a. Each of these agglomerates is formed of platelets with sizes of up to around $200 \mathrm{~nm}$, as can be seen in the dark field transmission electron microscopy image shown in Figure 3a. Each platelet is formed by nanocrystals with 
sizes below around $10 \mathrm{~nm}$. The backscattered electron image confirmed the presence of $\mathrm{Cu}_{2} \mathrm{O}$ sizes of up to around $1 \mu \mathrm{m}$ (see Figure 4).

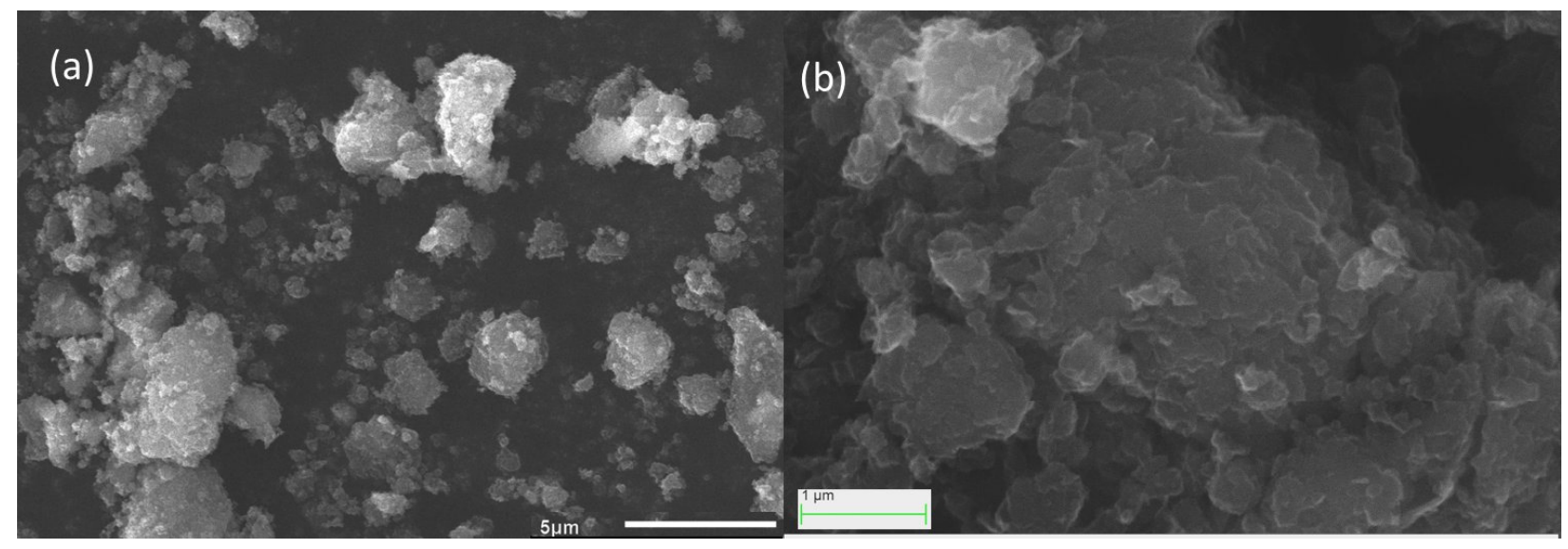

Figure 2. Secondary electron SEM images of graphite milled for 40 minutes.

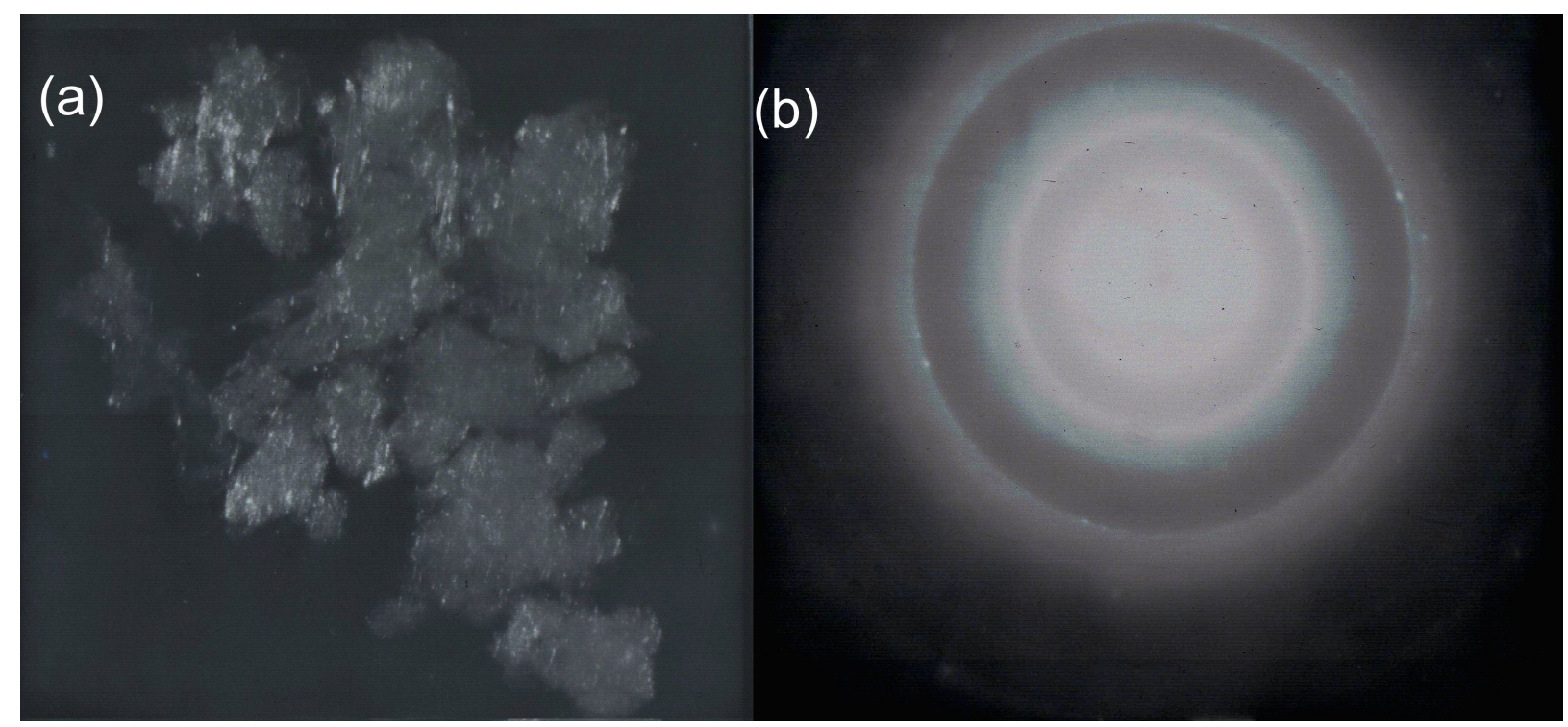

Figure 3. (a) Dark field TEM image of milled graphite, and (b) the corresponding selected area electron diffraction pattern. 


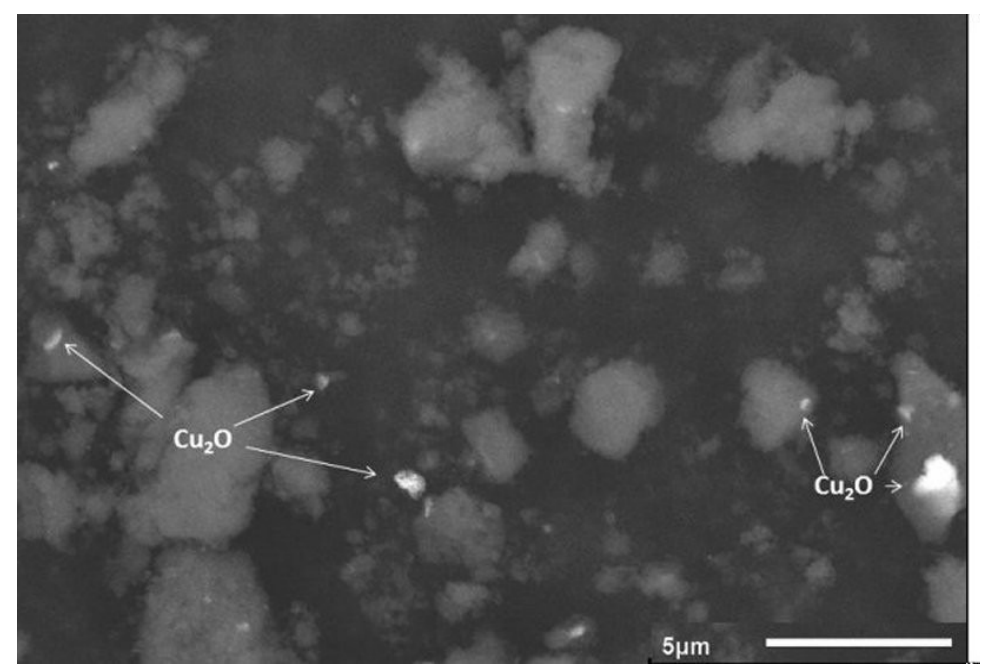

Figure 4. Backscattered electrons SEM image of milled graphite, after treatment with a $\mathrm{CuSO}_{4}$ solution in an ultrasonic bath. Bright particles correspond to $\mathrm{Cu}_{2} \mathrm{O}$.

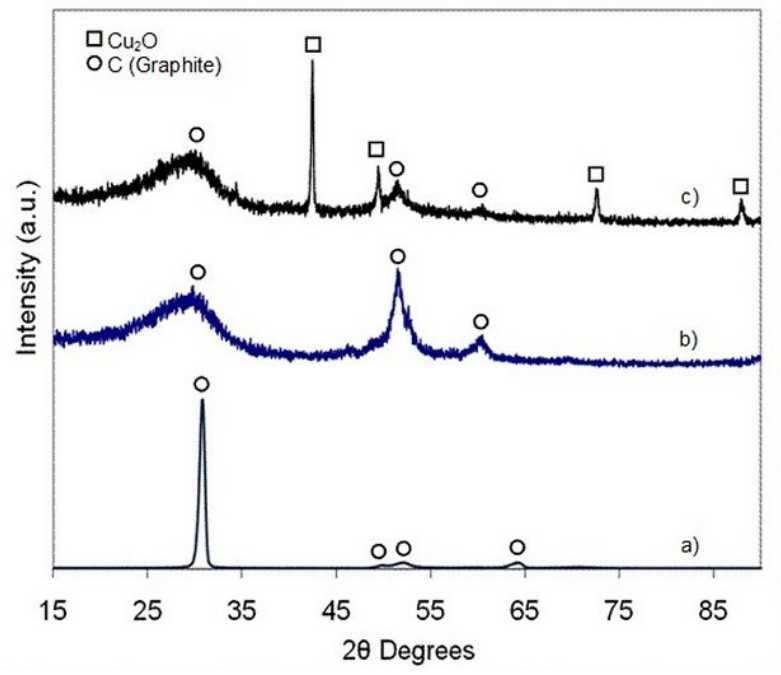

Figure 5. X-ray diffraction patterns of a) unmilled graphite, b) graphite milled for 40 minutes, and c) milled graphite, after treatment with $\mathrm{CuSO}_{4}$ solution in an ultrasonic bath. The formation of $\mathrm{Cu}_{2} \mathrm{O}$ can be observed.

Figure 5 shows the X-ray diffraction patterns of a) unmilled graphite, b) milled graphite and c) milled graphite after treatment with a $\mathrm{CuSO}_{4}$ solution followed by ultrasonication. The patterns shown in a) and b) correspond with the card JCPDS 23-64, for graphite. The peak broadening in Figure $5 \mathrm{~b}$ is due to crystallite size under $100 \mathrm{~nm},{ }^{12}$ in agreement with the nanoparticles shown in Figure 5a. The most noticeable peak broadening was produced in the direction perpendicular to (002) planes, as could be expected for weak bonding between basal planes in graphite. Figure 5c shows that the $\mathrm{Cu}_{2} \mathrm{O}$ (JCPDS 1-1142) was formed after 
ultrasonication of an aqueous $\mathrm{CuSO}_{4}$ solution containing suspended graphite (after drying at $120^{\circ} \mathrm{C}$ overnight). Assuming catalysis by $\mathrm{Cu}(\mathrm{I})$, reduction by charcoal could account for the observed activity as described by Lipshutz. ${ }^{8 \mathrm{a}}$

\section{(b) Application of the $\mathrm{Cu}_{2} \mathrm{O} / \mathrm{C}$ catalyst for the preparation of 1,5-disubstituted}

\section{1,2,3-triazoles}

The selected area electron-diffraction pattern of the copper is in agreement with the presence of $\mathrm{Cu}_{2} \mathrm{O} .{ }^{13}$ It is worthy of note that $\mathrm{Cu}_{2} \mathrm{O}$ very recently has been found to catalyze the 1,3-dipolar cycloaddition of azides and terminal alkynes. ${ }^{14}$ The reaction of benzyl azide (1a) with phenyl acetylene (2a) was chosen as a model system (Table 1). Initially, we attempted to adopt a previously reported reaction protocol [PS-EPG-terpyridine copper(I) complex $\left./ \mathrm{H}_{2} \mathrm{O} / 40^{\circ} \mathrm{C}\right]^{15}$ to synthesize the targeted product 3a, but to our surprise, 3a was not formed. Modification of the procedure reported by Chowdhury ${ }^{16}$ with increased catalyst loading and manipulation of various parameters (Table 1) including different solvent systems did, however, provide 3a. It was found that the solvent system plays a very important role in terms of reaction rate, isolated yields, and regioselectivity with the $50 \%$ aqueous isopropanol mixture being especially efficacious (Table 1 , entry 6). In addition, examination of the effect of various bases showed that triethylamine was the preferred one (Table 1). The TON and the turnover frequency (TOF) of the catalyst reached 1957.32 and $13.5 \mathrm{~h}^{-1}$, respectively; these are, as far as we know, one of the higher TON and TOF obtained for heterogeneous catalysts. ${ }^{8 \mathrm{a}, 17}$

With the optimized conditions (Table 1, entry 6) in hand, the scope of the reaction was explored by reacting various azido compounds (1a-f) with terminal alkynes (2a-e). The results are summarized in Table 2. All products were characterized by spectral and analytical data (see Experimental Section). The molecular structures of triazoles 3c, 3l, 3p and 3v were confirmed unambiguously by single-crystal X-ray analyses (see Figure 6). ${ }^{18}$ It is obvious that a wide variety of aryl, benzyl, and alkyl azides possessing different functional groups reacted successfully.

Table 1. 1,3-Dipolar Huisgen cycloaddition reaction of benzyl azide and phenylacetylene under various conditions

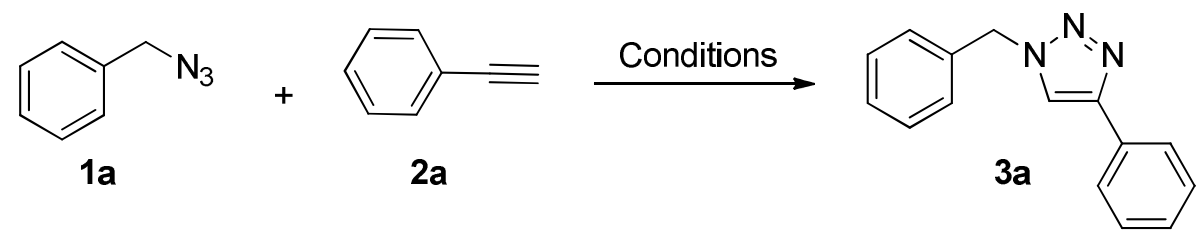

\begin{tabular}{clc}
\hline Entry & \multicolumn{1}{c}{ Conditions } & Yield $(\%)^{\mathrm{a}}$ \\
\hline 1 & Charcoal, (no $\left.\mathrm{Cu}_{2} \mathrm{O}\right)$, r.t., $2 \mathrm{~h}$ & 0 \\
2 & $\mathrm{H}_{2} \mathrm{O}$, with 5\% Catalyst, r.t., $2 \mathrm{~h}$ & 0 \\
3 & Acetonitrile, 5\% Catalyst, $\mathrm{Et}_{3} \mathrm{~N}$, r.t., $1 \mathrm{~h}$ & $78^{\mathrm{b}}$ \\
4 & Acetonitrile, 5\% Catalyst, $\mathrm{Et}_{3} \mathrm{~N}$, r.t., $24 \mathrm{~h}$ & 79 \\
5 & Acetonitrile, 10\% Catalyst, $\mathrm{Et}_{3} \mathrm{~N}$, r.t., $1 \mathrm{~h}$ & 81 \\
\hline
\end{tabular}


Table 1. Continued

\begin{tabular}{|c|c|c|}
\hline Entry & Conditions & Yield $(\%)^{\mathrm{a}}$ \\
\hline 6 & $\mathrm{H}_{2} \mathrm{O}$ :Isopropanol, $5 \%$ Catalyst, $\mathrm{Et}_{3} \mathrm{~N}$, r.t., $2 \mathrm{~h}$ & 82 \\
\hline 7 & $\mathrm{H}_{2} \mathrm{O}$ :Isopropanol, $10 \%$ Catalyst, $\mathrm{Et}_{3} \mathrm{~N}$, r.t., $2 \mathrm{~h}$ & 83 \\
\hline 9 & $\mathrm{H}_{2} \mathrm{O}$ :Isopropanol, $15 \%$ Catalyst, $\mathrm{Et}_{3} \mathrm{~N}$, r.t., $2 \mathrm{~h}$ & 77 \\
\hline 10 & $\mathrm{H}_{2} \mathrm{O}$ :Isopropanol, $20 \%$ Catalyst, $\mathrm{Et}_{3} \mathrm{~N}$, r.t., $2 \mathrm{~h}$ & 85 \\
\hline 11 & $\mathrm{H}_{2} \mathrm{O}:$ Isopropanol, $5 \%$ Catalyst, $\mathrm{K}_{2} \mathrm{CO}_{3}$, r.t., $24 \mathrm{~h}$ & 64 \\
\hline 12 & $\mathrm{H}_{2} \mathrm{O}$ :Isopropanol, $10 \%$ Catalyst, $\mathrm{K}_{2} \mathrm{CO}_{3}$, r.t., $24 \mathrm{~h}$ & 57 \\
\hline 13 & $\mathrm{H}_{2} \mathrm{O}$ :Isopropanol, $15 \%$ Catalyst, $\mathrm{K}_{2} \mathrm{CO}_{3}$, r.t., $24 \mathrm{~h}$ & 66 \\
\hline 14 & $\mathrm{H}_{2} \mathrm{O}$ :Isopropanol, $20 \%$ Catalyst, $\mathrm{K}_{2} \mathrm{CO}_{3}$, r.t., $24 \mathrm{~h}$ & 65 \\
\hline 15 & $\mathrm{H}_{2} \mathrm{O}$ :Isopropanol, $5 \%$ Catalyst, 2,6-lutidine, r.t., $24 \mathrm{~h}$ & $0^{\mathrm{c}}$ \\
\hline
\end{tabular}

${ }^{a}$ Chromatographically isolated yield of pure product. ${ }^{b}$ The catalyst was not recovered. ${ }^{c}$ No product formation was observed despite increasing the amount of 2,6-lutidine and catalyst.

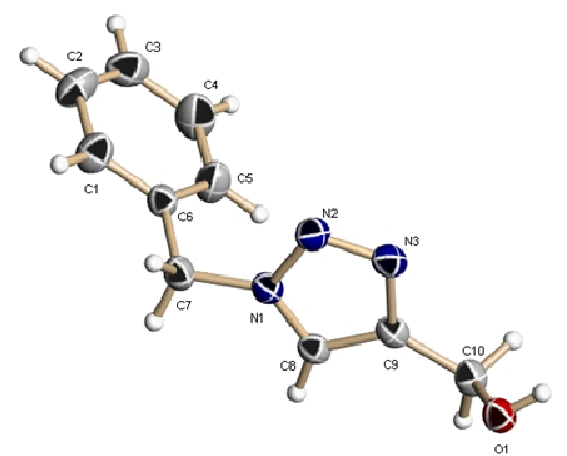

$3 c$

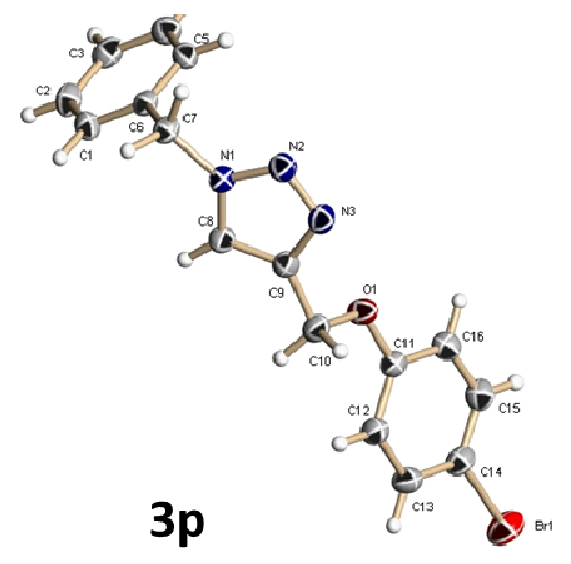

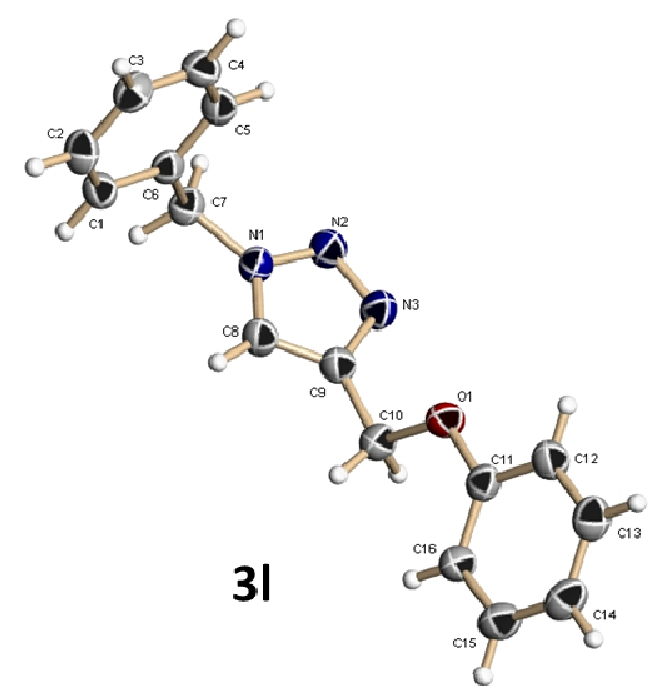

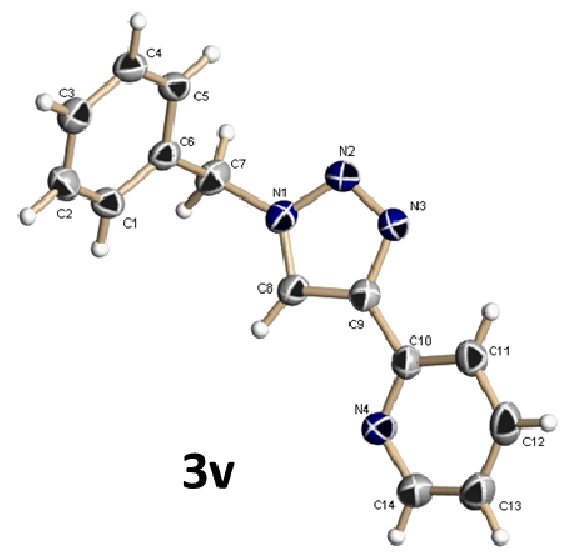

Figure 6. X-Ray structures of 3c, 3l, 3p and 3v. 
Table 2. Click reactions catalyzed by $\mathrm{Cu}_{2} \mathrm{O} / \mathrm{C}^{\mathrm{a}}$

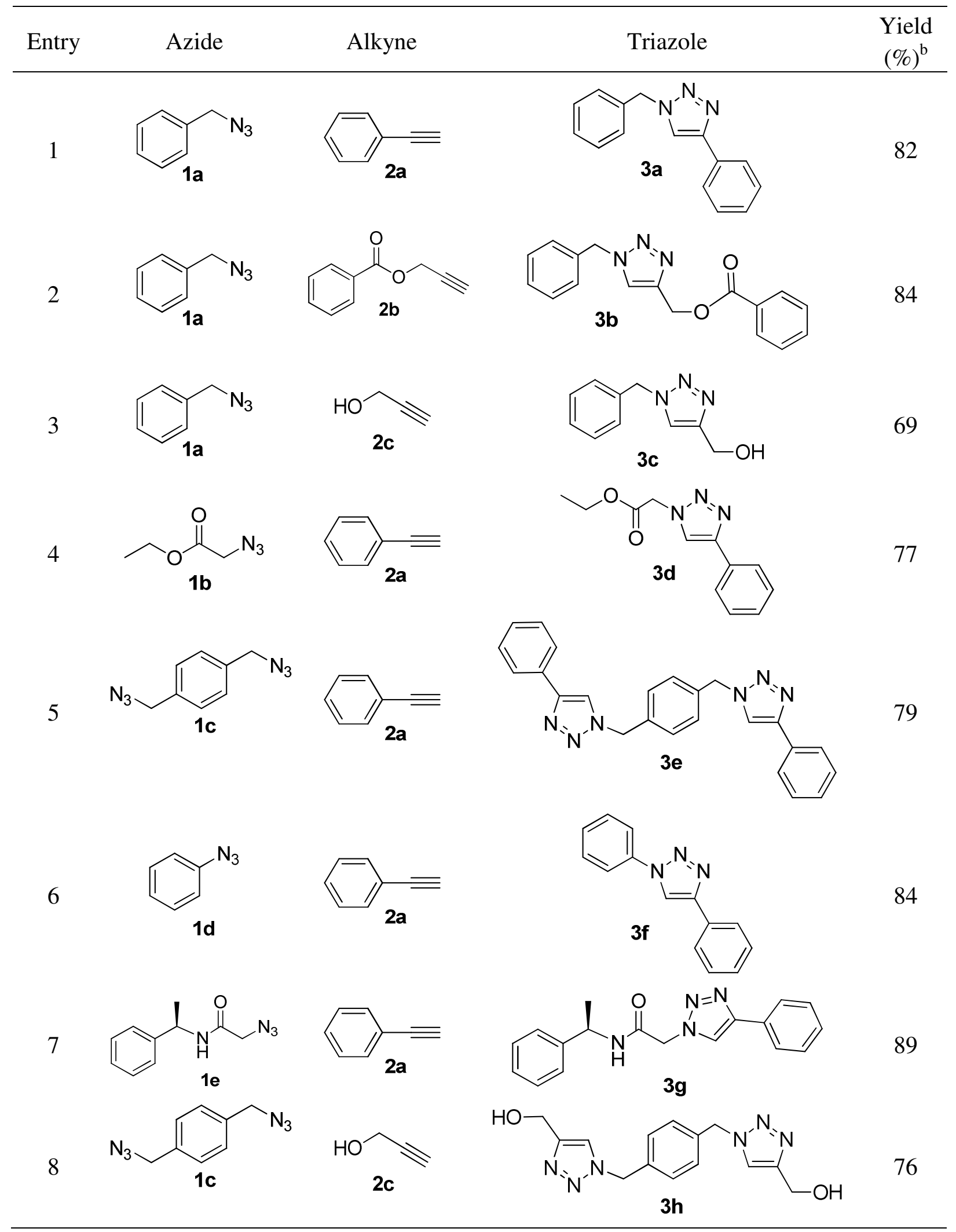


Table 2. Continued

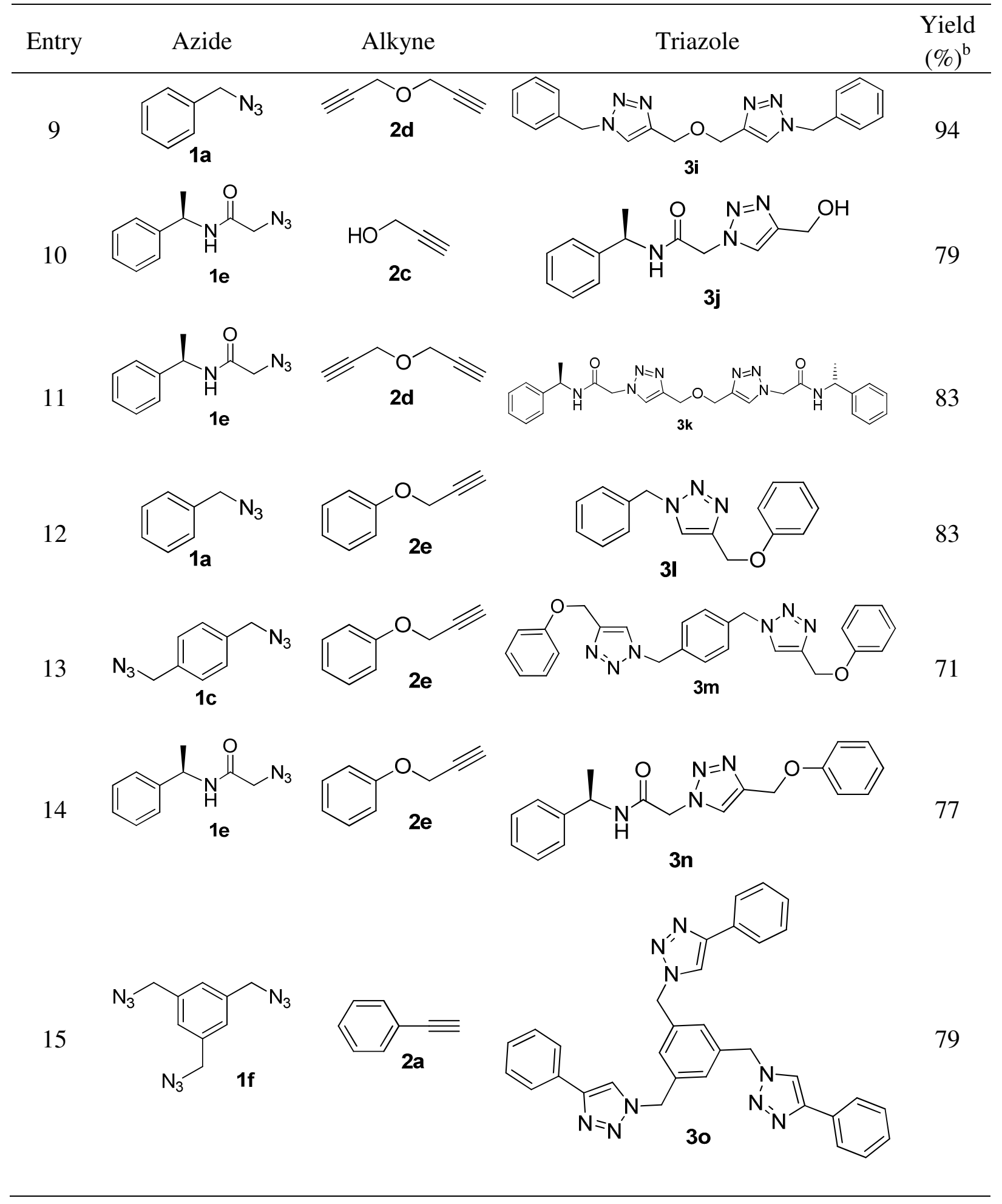


Table 2. Continued

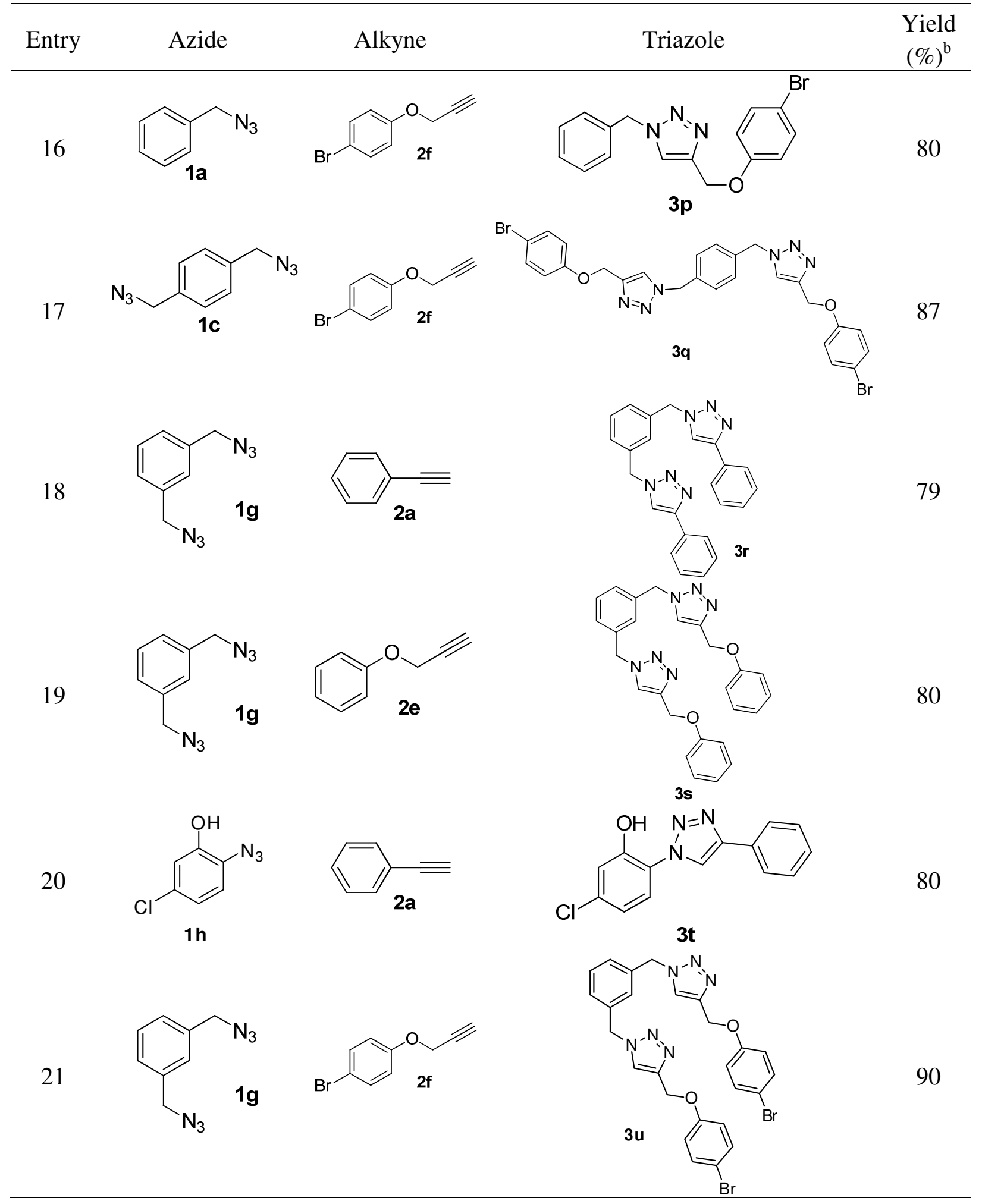


Table 2. Continued

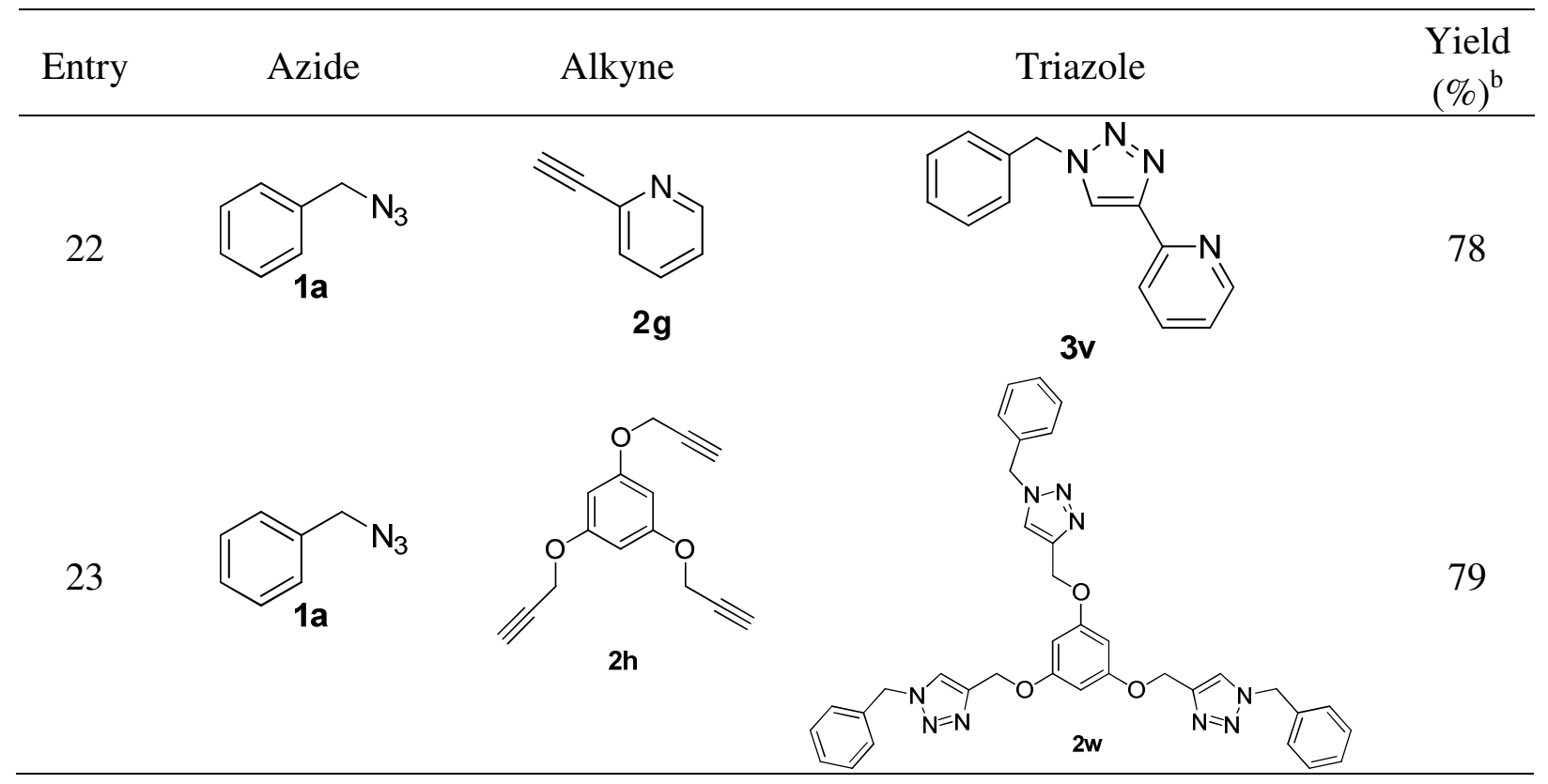

${ }^{\text {a }}$ Reaction was performed using $1 \mathrm{~mL}$ of $\mathrm{H}_{2} \mathrm{O}$ and $1 \mathrm{~mL}$ of Isopropanol at room temperature with $5 \mathrm{~mol} \% \mathrm{Cu}_{2} \mathrm{O} / \mathrm{C}$ and $1.1 \mathrm{~mL}$ of $\mathrm{Et}_{3} \mathrm{~N}$. ${ }^{\mathrm{b}}$ Product was further purified by silica gel chromatography.

\section{(c) Catalyst durability}

Numerous control experiments indicated not only that the $\mathrm{Cu}_{2} \mathrm{O} / \mathrm{C}$ on charcoal is essential for catalysis, but that it is also quite robust. For example, the recyclability of $\mathrm{Cu}_{2} \mathrm{O} / \mathrm{C}$ was examined for the click reaction of benzyl azide (1a) with phenylacetylene (2a). Thus after the first reaction, which give $82 \%$ of 1-benzyl-4-phenyl-1H-1,2,3-triazole (3a), the catalyst was recovered by simple filtration, washed with water, dried under vacuum, and reused three times under similar reaction conditions to give $\mathbf{3 a}$ in $78 \%$ and $61 \%$ yields (Scheme 2).<smiles>[N-]Cc1ccccc1</smiles>

$1 \mathrm{a}$

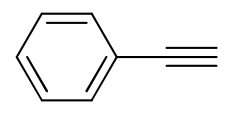

$2 \mathbf{a}$ $\underset{{ }^{i} \mathrm{PrOH}: \mathrm{H}_{2} \mathrm{O}(1: 1), \text { r.t. }}{\stackrel{5}{\longrightarrow}}$<smiles>c1ccc(Cn2cc(-c3ccccc3)nn2)cc1</smiles>

$82 \%$ yield (1st reuse) $78 \%$ yield (2nd reuse) $61 \%$ yield (3rd reuse)

\section{Scheme 2}

\section{(d) One pot procedure}

In an attempt to circumvent the risk of working with potentially explosive organic azides, we investigated the possibility of carrying out the click reaction without having to isolate the azides. 
It is known that 1,4-disubstituted 1,2,3-triazoles can be prepared efficiently in a two step one-pot procedure, in a CuI-zeolite-catalyzed synthesis of triazoles from halides or tosylates, sodium azide, and alkynes at $90^{\circ} \mathrm{C} .^{9 a}$ Benzyl bromide and phenylacetylene were selected as model compounds to find the appropriate conditions for the desired one-pot process. Various reaction conditions were examined including the amount of $\mathrm{Cu}_{2} \mathrm{O} / \mathrm{C}$, the reaction temperature, and different solvent systems. Once again 50\% aqueous isopropanol clearly stood out as the solvent system of choice providing a fast reaction rate at $80^{\circ} \mathrm{C}$ (reflux), high yield, and selectivity (see Table 3). The scope of the reaction was explored by reacting sodium azide, benzyl bromide or alkyl bromides (4a-d) with terminal alkynes (2a-d). The results are summarized in Table 3.

Table 3. One-pot $\mathrm{Cu}_{2} \mathrm{O} / \mathrm{C}$ synthesis of 1,4-disubstituted triazoles from halides and related compounds $^{\text {a }}$

Yield (\%)

${ }^{a}$ Run at 2 equiv of sodium azide, $1 \mathrm{~mL}$ of $\mathrm{H}_{2} \mathrm{O}$ and $1 \mathrm{~mL}$ of isopropanol at $80^{\circ} \mathrm{C}$ with $5 \mathrm{~mol} \%$ $\mathrm{Cu}_{2} \mathrm{O} / \mathrm{C}$ and 4 equiv. of $\mathrm{Et}_{3} \mathrm{~N}$ for $2 \mathrm{~h}$.

${ }^{\mathrm{b}}$ Product was further purified by silica gel chromatography. 


\section{(e) Application to other systems}

The synthesis of $\mathbf{7 a - e}$ was carried out following recently described methodology. ${ }^{19}$ This procedure involves the condensation of salicylaldehyde derivatives with 2-aminophenols in the presence of phenylboronic and catalytic potassium cyanide to give the 2-(2hydroxyphenyl)benzoxazole derivatives (7a-e). (Scheme 3)

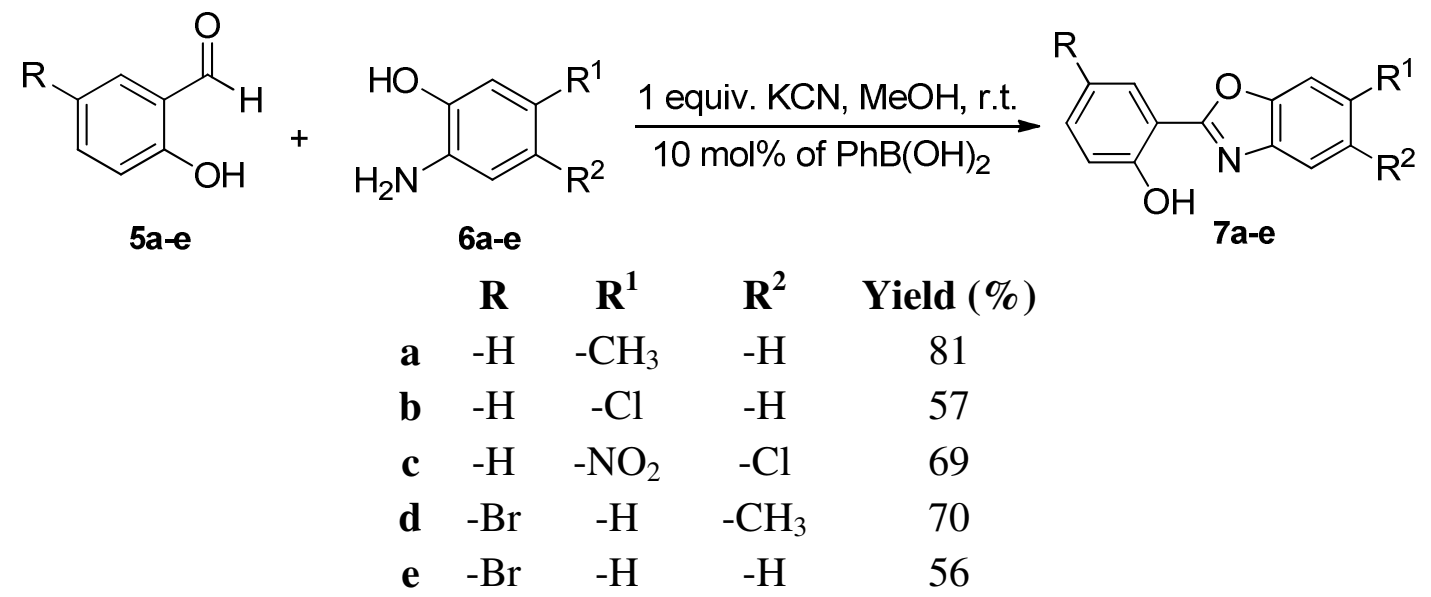

Scheme 3

The 2-(2-hydroxyphenyl)benzoxazole derivatives (7a-e) were subsequently alkylated with propargyl bromide in the presence of potassium carbonate to afford the corresponding benzoxazole derivatives 8a-e. These compounds, without purification, were reacted with benzyl azide, under the conditions described above to give the 1,2,3-triazole derivatives 9a-e. (Scheme 4). The structure of the 1,2,3-triazole derivatives 9a-e was unequivocally established by the usual spectroscopic means, as well as by X-ray crystal structure for compound 9d (Figure 7, vide infra). ${ }^{20}$

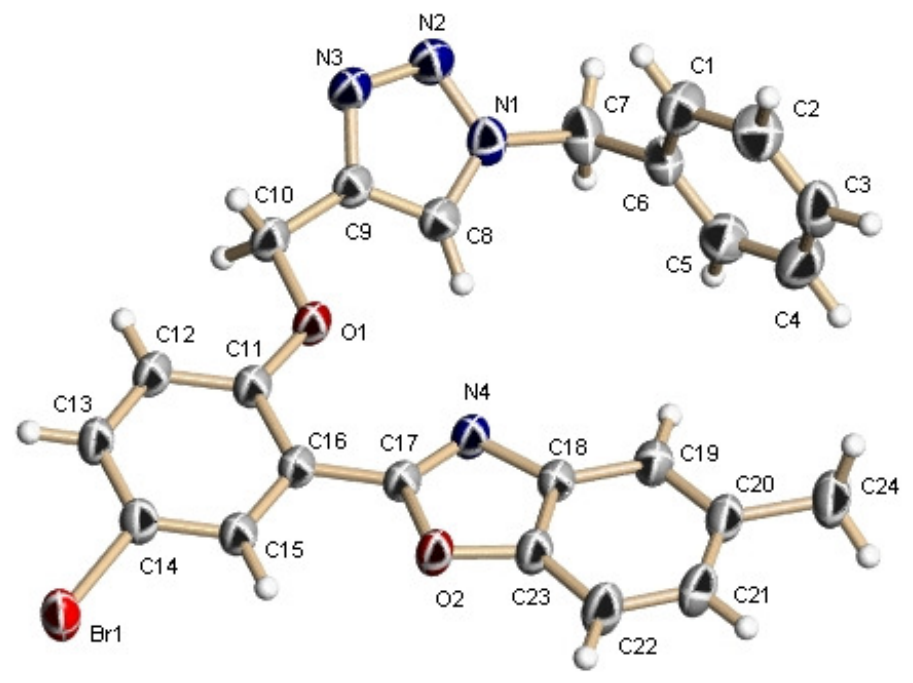

Figure 7. X-Ray structure of $9 d$. 

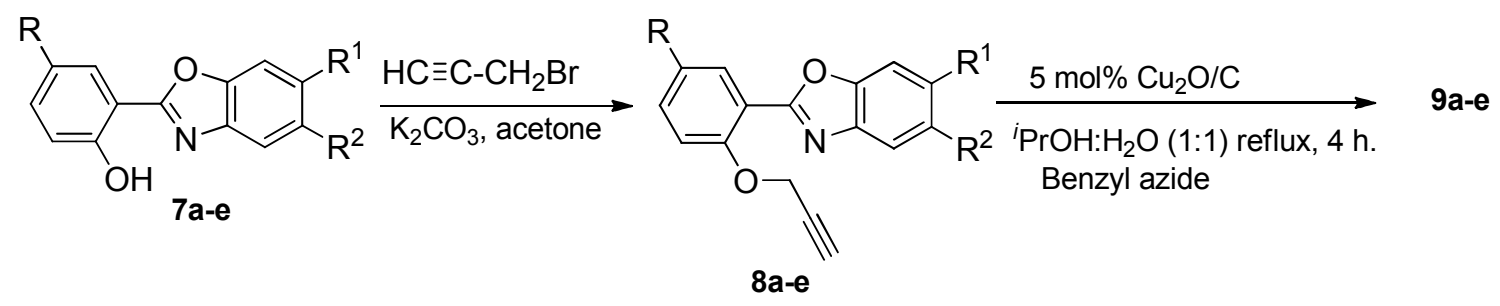

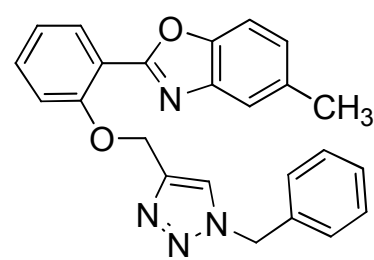

9a $(87 \%$ isolated yield)

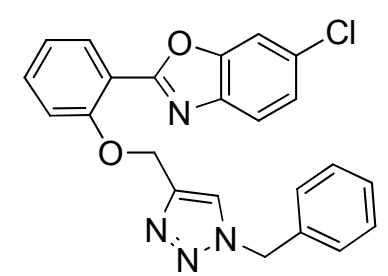

9b $(75 \%$ isolated yield $)$

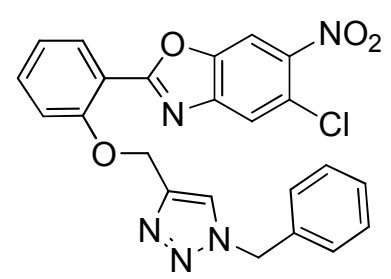

9c $(82 \%$ isolated yield $)$
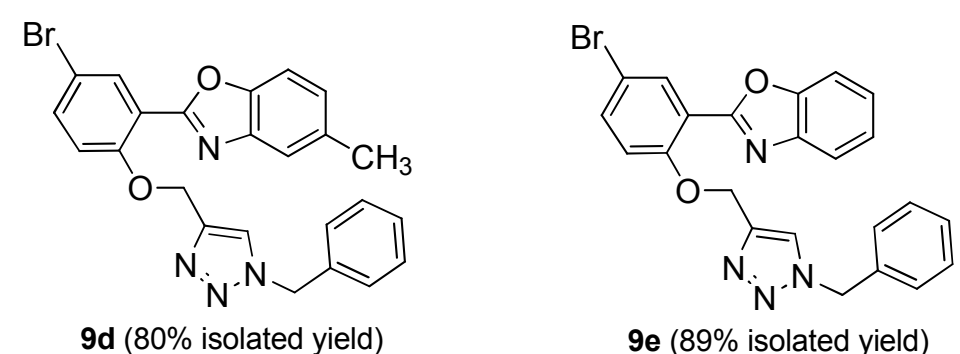

9 e $(89 \%$ isolated yield $)$

\section{Scheme 4}

The mechanism of these reactions proceeds similarly to previous reports. ${ }^{8 \mathrm{a}-\mathrm{b}, 21,22}$

\section{Conclusions}

We describe in this paper a facile preparation of a new supported catalyst $\left(\mathrm{Cu}_{2} \mathrm{O} / \mathrm{C}\right)$ for CopperCatalyzed Alkyne-Azide Cycloaddition. This material was found to efficiently catalyze the formation of several 1,4-disubstituted 1,2,3-triazoles from organic azides and various terminal alkynes. In addition, a multicomponent, one-pot protocol for the synthesis of 1,4-disubstituted 1,2,3-triazoles from alkyl azides was devised. Considering the good triazole yields, the operational ease with which these reactions can be carried out, and the inexpensive chemicals involved, we believe this protocol will be of great benefit to medicinal and synthetic organic chemistry.

\section{Experimental Section}

General. TLC was performed on Merck-DC-F ${ }_{254}$ plates, detection was made by shining UV light. Flash column chromatography was performed using Merck silica gel (230-240 mesh). 
Melting points were measured in open capillary tubes on a Büchi Melting Point B-540 apparatus and have not been corrected. ${ }^{1} \mathrm{H}$ and ${ }^{13} \mathrm{C}$ NMR spectra were recorded on a JEOL Eclipse+400 (400 MHz, $100 \mathrm{MHz}$ )) and a Varian VNMRS 400 (400 and $100 \mathrm{MHz}$ ) spectrometers. Chemical shifts $(\delta)$ are indicated in ppm downfield from internal TMS used as reference; the coupling constants $(J)$ are given in Hz. IR spectra were measured on a Perkin Elmer GX FT-IR. Elemental analyses were performed on a Perkin-Elmer Series II CHNS/O Analyzer 2400.

\section{General procedure for the preparation of 1,2,3-triazoles}

In a $10 \mathrm{~mL}$ round-bottomed flask fitted with a magnetic stirring bar was placed 1.0 equiv. of azide 1 and 1.0 equiv. of terminal alkyne 2 in $2 \mathrm{~mL}$ of $\left[\mathrm{H}_{2} \mathrm{O}:{ }^{i} \mathrm{PrOH}(1: 1)\right]$, further was added $\mathrm{Cu}_{2} \mathrm{O} / \mathrm{C}(5 \% \mathrm{w} / \mathrm{w})$ and $1.1 \mathrm{~mL}$ of $\mathrm{Et}_{3} \mathrm{~N}$ (for $100 \mathrm{mg}$ of alkyl azide). The reaction mixture was warmed to $80{ }^{\circ} \mathrm{C}$ and monitored by TLC until total conversion of the starting material. The crude reaction mixture was filtered through a filter paper, washed and extracted with EtOAc or $\mathrm{CH}_{2} \mathrm{Cl}_{2}$ $(3 \times 20 \mathrm{~mL})$. The combined organic extracts were washed with $15 \mathrm{~mL}$ of saturated aq. $\mathrm{NH}_{4} \mathrm{Cl}$, dried over anhydrous sodium sulfate, and evaporated under reduced pressure in vacuum. The crude reaction mixture was purified by column chromatography or crystallization to afford 3a-w.

\section{General procedure for the one-pot direct synthesis of 1,2,3-triazoles}

In a $10 \mathrm{~mL}$ round-bottomed flask fitted with a magnetic stirring bar was placed 1.0 equiv. of alkyl halide 4, 2 equiv. of sodium azide in $2 \mathrm{~mL}$ of $\left[\mathrm{H}_{2} \mathrm{O}:{ }^{i} \mathrm{PrOH}(1: 1)\right], 1.0$ equiv. of terminal alkyne $2, \mathrm{Cu}_{2} \mathrm{O} / \mathrm{C}(5 \% \mathrm{w} / \mathrm{w})$ and $1.1 \mathrm{~mL}$ of $\mathrm{Et}_{3} \mathrm{~N}$ (for $0.734 \mathrm{mmol}$ of alkyl halide). The reaction mixture was warmed to $80{ }^{\circ} \mathrm{C}$ and monitored by TLC until total conversion of the starting material. The crude reaction mixture was filtered through a filter paper, washed and extracted with EtOAc or $\mathrm{CH}_{2} \mathrm{Cl}_{2}(3 \times 20 \mathrm{~mL})$. The combined organic extracts were washed with $15 \mathrm{~mL}$ of saturated aq. $\mathrm{NH}_{4} \mathrm{Cl}$, dried over anhydrous sodium sulfate, and evaporated under reduced pressure in vacuum. The crude reaction mixture was purified by column chromatography or crystallization to afford 3a-e and 3g-i.

1-Benzyl-4-phenyl-1H-1,2,3-triazole (3a). ${ }^{\text {7a,8a,8d,9a,15,23,24 }}$ The general procedure was followed using $0.1 \mathrm{~g}(0.734 \mathrm{mmol})$ of benzyl azide $(\mathbf{1 a}), 0.81 \mathrm{~mL}(0.734 \mathrm{mmol})$ of phenylacetylene, $5 \mathrm{mg}$ of $\mathrm{Cu}_{2} \mathrm{O} / \mathrm{C}$ and $1.1 \mathrm{~mL}$ of $\mathrm{Et}_{3} \mathrm{~N}$ to give $0.139 \mathrm{~g}(82 \%)$ of $\mathbf{3 a}$ as a white solid. Purification was performed by crystallization using (ethyl acetate/diethyl ether). Mp $131-133{ }^{\circ} \mathrm{C}$ (lit. ${ }^{23 a} \mathrm{mp}: 130$ $132^{\circ} \mathrm{C}$; lit. $\left.{ }^{8 \mathrm{c}} \mathrm{mp}: 129-129.5^{\circ} \mathrm{C}\right)$.

(1-Benzyl-1H-1,2,3-triazol-4-yl)methyl benzoate (3b). The general procedure was followed using $0.10 \mathrm{~g}(0.734 \mathrm{mmol})$ of benzyl azide $(\mathbf{1 a}), 0.10 \mathrm{~mL}(0.734 \mathrm{mmol})$ of propargyl benzoate, 5 $\mathrm{mg}$ of $\mathrm{Cu}_{2} \mathrm{O} / \mathrm{C}$ and $1.1 \mathrm{~mL}$ of $\mathrm{Et}_{3} \mathrm{~N}$ to give $0.180 \mathrm{~g}(84 \%)$ of $\mathbf{3 b}$ as a white solid. The solid residue was purified by crystallization using (ethyl acetate/diethyl ether). Mp 106-109 ${ }^{\circ} \mathrm{C}$; IR (film) $v_{\max } / \mathrm{cm}^{-1}: 3070,1722,1603,1453,1275,1111,1052,956,713 ;{ }^{1} \mathrm{H}$ NMR (400 MHz,

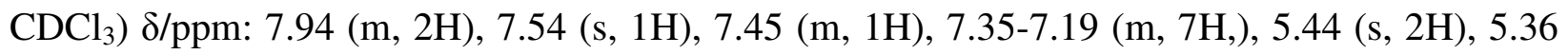
(s, 2H). ${ }^{13} \mathrm{C} \mathrm{NMR}\left(\mathrm{CDCl}_{3}, 100 \mathrm{MHz}\right) \delta / \mathrm{ppm}: 166.4,143.3,134.3,133.2,129.8,129.6,129.1$, 
128.8, 128.3, 128.1, 123.8, 58.0, 54.2 Anal. Calcd for $\mathrm{C}_{17} \mathrm{H}_{15} \mathrm{~N}_{3} \mathrm{O}_{2} \mathrm{C}, 69.61 ; \mathrm{H}, 5.15 ; \mathrm{N}, 14.33$. Found: C, 69.98; H, 4.86; N, 13.96\%.

(1-Benzyl-1H-1,2,3-triazol-4-yl)methanol (3c). ${ }^{8 c, 18 a, 25}$ The general procedure was followed using $0.10 \mathrm{~g}(0.734 \mathrm{mmol})$ of benzyl azide $(\mathbf{1 a}), 0.16 \mathrm{~mL}(1.1 \mathrm{mmol})$ of propargyl alcohol, $5 \mathrm{mg}$ of $\mathrm{Cu}_{2} \mathrm{O} / \mathrm{C}$ and $1.1 \mathrm{~mL}$ of $\mathrm{Et}_{3} \mathrm{~N}$ to give $0.096 \mathrm{~g}(69 \%)$ of $\mathbf{3 c}$ as a white solid. The solid residue was purified by crystallization using (hexane/diethyl ether). $\mathrm{Mp} 77-79^{\circ} \mathrm{C}$ (lit. ${ }^{8 \mathrm{c}} \mathrm{mp}: 78-78.5^{\circ} \mathrm{C}$.

Ethyl 2-(4-phenyl-1H-1,2,3-triazol-1-yl)acetate $(\mathbf{3 d}) .^{8 \mathrm{~d}, 10,23 \mathrm{a}, 24 \mathrm{a}}$ The general procedure was followed using $0.10 \mathrm{~g}(0.825 \mathrm{mmol})$ of ethyl azidoacetate $(\mathbf{1 b}), 0.09 \mathrm{~mL}(0.825 \mathrm{mmol})$ of phenylacetylene, $5 \mathrm{mg}$ of $\mathrm{Cu}_{2} \mathrm{O} / \mathrm{C}$ and $1.1 \mathrm{~mL}$ of $\mathrm{Et}_{3} \mathrm{~N}$ to give $0.150 \mathrm{~g}(77 \%)$ of $\mathbf{3 d}$ as a white solid. The solid residue was purified by crystallization using (hexane/diethyl ether). Mp 94-96 ${ }^{\circ} \mathrm{C}$ (lit. ${ }^{23 \mathrm{a}} \mathrm{mp}$ : $93-95{ }^{\circ} \mathrm{C}$; lit. ${ }^{10} \mathrm{mp}$ : $94-95{ }^{\circ} \mathrm{C}$ ).

1,4-Bis[(4-phenyl-1H-1,2,3-triazol-1-yl)methyl]benzene (3e). The general procedure was followed using $0.10 \mathrm{~g}(0.531 \mathrm{mmol})$ of 1,4-bis(azidomethyl)benzene $(\mathbf{1 c}), 0.116 \mathrm{~mL}$ (1.06 mmol) of phenylacetylene, $5 \mathrm{mg}$ of $\mathrm{Cu}_{2} \mathrm{O} / \mathrm{C}$ and $1.1 \mathrm{~mL}$ of $\mathrm{Et}_{3} \mathrm{~N}$ to give $0.280 \mathrm{~g}(79 \%)$ of $3 \mathbf{e}$ as a yellow solid. The solid residue was purified by flash chromatography using (ethyl acetate / hexane). Mp 253-255 ${ }^{\circ} \mathrm{C}$; IR (film) $v_{\max } / \mathrm{cm}^{-1}: 3098,2924,1470,1363,772,482 ;{ }^{1} \mathrm{H}$ NMR $\left(400 \mathrm{MHz}, \mathrm{CDCl}_{3}\right)$

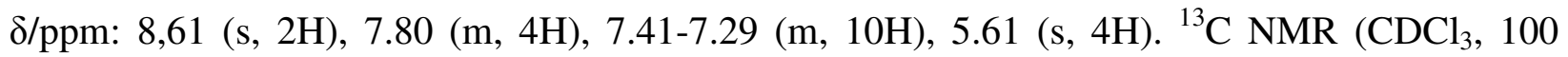

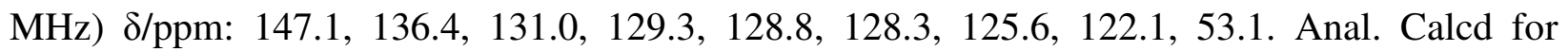
$\mathrm{C}_{24} \mathrm{H}_{20} \mathrm{~N}_{6} \mathrm{C}, 73.45 ; \mathrm{H}, 5.14 ; \mathrm{N}, 21.41$. Found: C, 73.25; H, 4.98; N, 21.32\%.

1,4-diphenyl-1H-1,2,3-triazole (3f). ${ }^{10 a, 23 a, 23 b, 23 d, 24 a}$ The general procedure was followed using $0.515 \mathrm{~g}(4.3 \mathrm{mmol})$ of phenyl azide $(\mathbf{1 d}), 0.47 \mathrm{~mL}(4.3 \mathrm{mmol})$ of phenylacetylene, $5 \mathrm{mg}$ of $\mathrm{Cu}_{2} \mathrm{O} / \mathrm{C}$ and $5.6 \mathrm{~mL}$ of $\mathrm{Et}_{3} \mathrm{~N}$ to give $0.767 \mathrm{~g}(84 \%)$ of $\mathbf{3 f}$ as a yellow solid. The solid residue was purified by crystallization using (dichloromethane/diethyl ether). Mp $183-185^{\circ} \mathrm{C}$ (lit. ${ }^{23 \mathrm{a}} \mathrm{mp}$ : 183 $\left.184^{\circ} \mathrm{C}\right)$.

(R)-2-(4-Phenyl-1H-1,2,3-triazol-1-yl)- $\mathbf{N}$-(1-phenylethyl)acetamide (3g). The general procedure was followed using $0.480 \mathrm{~g}(2.35 \mathrm{mmol})$ of $(R)$-2-azido- $N$-(1-phenylethyl)acetamide $(\mathbf{1 e}), 0.258$ $\mathrm{mL}(2.35 \mathrm{mmol})$ of phenylacetylene, $25 \mathrm{mg}$ of $\mathrm{Cu}_{2} \mathrm{O} / \mathrm{C}$ and $5.3 \mathrm{~mL}$ of $\mathrm{Et}_{3} \mathrm{~N}$ to give $0.640 \mathrm{~g}$ $(89 \%)$ of $\mathbf{3 g}$ as a white solid. The solid residue was purified by crystallization using (hexane/diethyl ether). Mp 244-245 ${ }^{\circ} \mathrm{C}$; IR (film) $v_{\max } / \mathrm{cm}^{-1}: 3275,3095,1658,1561,750,688$; ${ }^{1} \mathrm{H}$ NMR (DMSO- $\left.d_{6}, 400 \mathrm{MHz}\right) \delta / \mathrm{ppm}: 8.86$ (d, 1H, J 6.4 Hz), 8.47 (s, 1H), 7.81 (m, 2H), 7.41$7.20(\mathrm{~m}, 8 \mathrm{H}), 5.15(\mathrm{~s}, 2 \mathrm{H}), 4.90(\mathrm{~m}, 1 \mathrm{H}), 1.36(\mathrm{~d}, 3 \mathrm{H}, J 6.8 \mathrm{~Hz}) .{ }^{13} \mathrm{C}$ NMR (DMSO- $\left.d_{6}, 100 \mathrm{MHz}\right)$

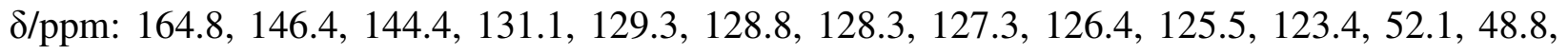
22.8. Anal. Calcd for $\mathrm{C}_{18} \mathrm{H}_{18} \mathrm{~N}_{4} \mathrm{O}$ C, 70.57; H, 5.92; N, 18.29. Found: C, 70.31; H, 5.69; N, $18.65 \%$.

[1,1-[1,4-phenylenebis(methylene)]bis(1H-1,2,3-triazol-4,1-diyl)]dimethanol (3h). The general procedure was followed using $0.10 \mathrm{~g}(0.531 \mathrm{mmol})$ of 1,4-bis(azidomethyl)benzene (1c), 0.065 $\mathrm{mL}(1.06 \mathrm{mmol})$ of propargyl alcohol, $5 \mathrm{mg}$ of $\mathrm{Cu}_{2} \mathrm{O} / \mathrm{C}$ and $1.1 \mathrm{~mL}^{\circ} \mathrm{Et}_{3} \mathrm{~N}$ to give $0.767 \mathrm{~g}$ $(84 \%)$ of $\mathbf{3 h}$ as a yellow solid. The solid residue was purified by crystallization using (ethyl acetate/diethyl ether). Mp 71-74 ${ }^{\circ} \mathrm{C}$; IR (film) $v_{\max } / \mathrm{cm}^{-1}: 3163,2928,1652,1467,1258,1041$, 860, 766; ${ }^{1} \mathrm{H}$ NMR (DMSO- $\left.d_{6}, 400 \mathrm{MHz}\right) \delta / \mathrm{ppm}: 7.98$ (s, 2H), 7.37 (s, 4H), 5.54 (s, 4H), 5.15 
(m, 2H), 4.44 (m, 4H). ${ }^{13} \mathrm{C}$ NMR (DMSO- $\left.d_{6}, 100 \mathrm{MHz}\right) \delta / \mathrm{ppm}: 148.8,135.9,129.2,123.3,55.4$, 53.6. Anal. Calcd for $\mathrm{C}_{14} \mathrm{H}_{16} \mathrm{~N}_{6} \mathrm{O}_{2} \mathrm{C}, 55.99 ; \mathrm{H}, 5.36 ; \mathrm{N}, 27.98$. Found: C, 55.71; H, 4.99; N, $27.72 \%$.

4,4-[Oxybis(methylene)]bis(1-benzyl-1H-1,2,3-triazole) $\left(3 \mathbf{3 i} .^{7 \mathrm{a}}\right.$ The general procedure was followed using $0.10 \mathrm{~g}(0.367 \mathrm{mmol})$ of benzyl azide (1a), $0.047 \mathrm{~mL}$ (1.06 mmol) of propargyl ether, $5 \mathrm{mg}$ of $\mathrm{Cu}_{2} \mathrm{O} / \mathrm{C}$ and $1.1 \mathrm{~mL}$ of $\mathrm{Et}_{3} \mathrm{~N}$ to give $0.248 \mathrm{~g}(94 \%)$ of $\mathbf{3 i}$ as a yellow solid. The solid residue was purified by crystallization using (dichloromethane/diethyl ether). Mp 124-126 ${ }^{\circ} \mathrm{C}$; IR (film) $v_{\max } / \mathrm{cm}^{-1}: 3141,2937,2869,1606,1457,1223,1129,1055,728 ;{ }^{1} \mathrm{H}$ NMR $\left(\mathrm{DMSO}-d_{6}, 400 \mathrm{MHz}\right) \delta / \mathrm{ppm}: 8.13(\mathrm{~s}, 2 \mathrm{H}), 7.34-7.24(\mathrm{~m}, 10 \mathrm{H}), 5.54(\mathrm{~s}, 4 \mathrm{H}), 4.50(\mathrm{~s}, 4 \mathrm{H}), .{ }^{13} \mathrm{C}$ NMR (DMSO- $\left.d_{6}, 100 \mathrm{MHz}\right) \delta / \mathrm{ppm}: 144.3,136.5,129.1,128.5,128.3,124.6,63.1,53.1$. Anal. Calcd for $\mathrm{C}_{20} \mathrm{H}_{20} \mathrm{~N}_{6} \mathrm{O}$ C, 66.65; H, 5.59; N, 23.32. Found: C, 66.40; H, 5.40; N, 22.99\%.

(R)-2-[4-(Hydroxymethyl)-1H-1,2,3-triazol-1-yl]- $N$-(1-phenylethyl)acetamide (3j). The general procedure was followed using $0.20 \mathrm{~g}(0.979 \mathrm{mmol})$ of $(R)$-2-azido- $N$-(1-phenylethyl)acetamide (1e), $0.058 \mathrm{~mL}(1.06 \mathrm{mmol})$ of propargyl alcohol, $10 \mathrm{mg}$ of $\mathrm{Cu}_{2} \mathrm{O} / \mathrm{C}$ and $2.2 \mathrm{~mL}$ of $\mathrm{Et}_{3} \mathrm{~N}$ to give $0.189 \mathrm{~g}(79 \%)$ of $\mathbf{3 j}$ as a yellow solid. The solid residue was purified by crystallization using (ethyl acetate/diethyl ether). Mp 92-94 ${ }^{\circ} \mathrm{C}$; IR (film) $v_{\max } / \mathrm{cm}^{-1}: 2934,1670,1562,1252,1041$, $702 ;{ }^{1} \mathrm{H}$ NMR (DMSO- $\left.d_{6}, 400 \mathrm{MHz}\right) \delta / \mathrm{ppm}: 8.78(\mathrm{~m}, 1 \mathrm{H}), 7.85(\mathrm{~s}, 1 \mathrm{H}), 7.30-7.20(\mathrm{~m}, 5 \mathrm{H}), 5.07$ $(\mathrm{s}, 2 \mathrm{H}), 4.88(\mathrm{~m}, 1 \mathrm{H}), 4.45(\mathrm{~d}, 2 \mathrm{H}, J 5.6 \mathrm{~Hz}), 1.33(\mathrm{~d}, 3 \mathrm{H}, J 7.2 \mathrm{~Hz}) .{ }^{13} \mathrm{C}$ NMR (DMSO-d 6,100

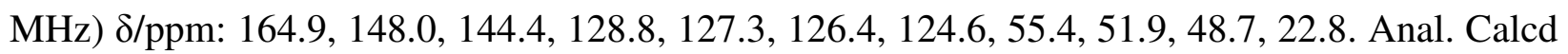
for $\mathrm{C}_{13} \mathrm{H}_{16} \mathrm{~N}_{4} \mathrm{O}_{2} \mathrm{C}, 59.99 ; \mathrm{H}, 6.20 ; \mathrm{N}, 21.52$. Found C, 60.22; H, 6.64; N, $21.71 \%$.

2,2-[4,4-[Oxybis(methylene)bis(1H-1,2,3-triazole-4,1-diyl)]]bis- $N$-[(R)-1-phenylethyl]acetamide (3k). The general procedure was followed using $0.210 \mathrm{~g}(1.02 \mathrm{mmol})$ of $(R)$-2-azido- $N$ (1-phenylethyl)acetamide (1e), $0.048 \mathrm{~mL}(1.06 \mathrm{mmol})$ of propargyl ether, $10 \mathrm{mg}$ of $\mathrm{Cu}_{2} \mathrm{O} / \mathrm{C}$ and $2.3 \mathrm{~mL}$ of $\mathrm{Et}_{3} \mathrm{~N}$ to give $0.603 \mathrm{~g}(83 \%)$ of $\mathbf{3 k}$ as a yellow solid. The solid residue was purified by flash chromatography using ethyl acetate/hexane. Mp $182-184{ }^{\circ} \mathrm{C}$; IR (film) $v_{\max } / \mathrm{cm}^{-1}: 3300$, 2976, 2681, 2499, 1669, 1565, 1059, $701 ;{ }^{1} \mathrm{H}$ NMR (DMSO- $d_{6}, 400 \mathrm{MHz}$ ) $\delta / \mathrm{ppm}: 8.96$ (m, 2H), $8.01(\mathrm{~s}, 2 \mathrm{H}), 7.29-7.18(\mathrm{~m}, 10 \mathrm{H}), 5.13(\mathrm{~s}, 4 \mathrm{H}), 4.87(\mathrm{~m}, 2 \mathrm{H}), 4.51(\mathrm{~s}, 4 \mathrm{H}), 1.34(\mathrm{~d}, 6 \mathrm{H}, J 6.8 \mathrm{~Hz})$. ${ }^{13} \mathrm{C}$ NMR (DMSO- $\left.d_{6}, 100 \mathrm{MHz}\right) \delta / \mathrm{ppm}: 164.9,144.5,143.7,128.5,127.5,126.4,126.1,62.9$, 51.9, 48.8, 22.9.

1-Benzyl-4-(phenoxymethyl)-1H-1,2,3-triazole (3l). ${ }^{1 \mathrm{c}, 8 \mathrm{~d}, 15,23 \mathrm{~b}, 25}$ The general procedure was followed using $0.10 \mathrm{~g}(0.734 \mathrm{mmol})$ of benzyl azide $(\mathbf{1 a}), 0.097 \mathrm{~g}(0.734 \mathrm{mmol})$ of (prop-2-yn-1yloxy)benzene (2e), $5 \mathrm{mg}$ of $\mathrm{Cu}_{2} \mathrm{O} / \mathrm{C}$ and $1.1 \mathrm{~mL}$ of $\mathrm{Et}_{3} \mathrm{~N}$ to give $0.161 \mathrm{~g}(83 \%)$ of $\mathbf{3 l}$ as a white solid. The solid residue was purified by crystallization using (ethyl acetate/diethyl ether). Mp 126-128 ${ }^{\circ} \mathrm{C}$; IR (film) $v_{\max } / \mathrm{cm}^{-1}: 3134,1599,1495,1224,1007,756 ;{ }^{1} \mathrm{H} \mathrm{NMR}\left(\mathrm{CDCl}_{3}, 400\right.$ $\mathrm{MHz}) \delta / \mathrm{ppm}: 7.51(\mathrm{~s}, 1 \mathrm{H}), 7.35-7.23(\mathrm{~m}, 7 \mathrm{H}),, 6.95-6.93(\mathrm{~m}, 3 \mathrm{H}), 5.47(\mathrm{~s}, 2 \mathrm{H}), 5.15(\mathrm{~s}, 2 \mathrm{H}) .{ }^{13} \mathrm{C}$

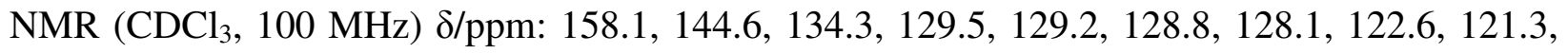
114.7, 61.9, 59.3. Anal. Calcd for $\mathrm{C}_{16} \mathrm{H}_{15} \mathrm{~N}_{3} \mathrm{O}$ C, 72.43; H, 5.70; N, 15.84. Found: C, 72.48; H, $5.62 ; \mathrm{N}, 15.98 \%$.

1,4-Bis[[4-(phenoxymethyl)-1H-1,2,3-triazol-1-yl]methyl]benzene $\mathbf{( 3 m )}$. The general procedure was followed using $0.15 \mathrm{~g}(0.797 \mathrm{mmol})$ of 1,4-bis(azidomethyl)benzene (1c), $0.240 \mathrm{~g}$ (1.59 
mmol) of (prop-2-yn-1-yloxy)benzene (2e), $7.5 \mathrm{mg}$ of $\mathrm{Cu}_{2} \mathrm{O} / \mathrm{C}$ and $1.65 \mathrm{~mL}$ of $\mathrm{Et}_{3} \mathrm{~N}$ to give $0.255 \mathrm{~g}(71 \%)$ of $\mathbf{3 m}$ as a white solid. The solid residue was purified by crystallization using (ethyl acetate/diethyl ether). Mp 192-194 ${ }^{\circ} \mathrm{C}$; IR (film) $v_{\max } / \mathrm{cm}^{-1}: 3145,1595,1433,1212,1006$, $758 ;{ }^{1} \mathrm{H}$ NMR $\left(\mathrm{CDCl}_{3}, 400 \mathrm{MHz}\right) \delta / \mathrm{ppm}: 7.53$ (s, 2H), 7.27-7.23 (m, 8H), 6.94-6.92 (m, 6H), $5.50(\mathrm{~s}, 4 \mathrm{H}), 5.17(\mathrm{~s}, 4 \mathrm{H}) .{ }^{13} \mathrm{C} \mathrm{NMR}\left(\mathrm{CDCl}_{3}, 100 \mathrm{MHz}\right) \delta / \mathrm{ppm}: 158.1,144.8,135.2,129.6$, 128.8, 122.7, 121.3, 114.7, 61.9, 53.7. Anal. Calcd for $\mathrm{C}_{26} \mathrm{H}_{24} \mathrm{~N}_{6} \mathrm{O}_{2} \mathrm{C}, 69.01 ; \mathrm{H}, 5.35 ; \mathrm{N}, 18.57$. Found: C, 69.07; H, 5.16; N, 18.44\%.

(R)-2-[4-(Phenoxymethyl)-1H-1,2,3-triazol-1-yl]- $N$-(1-phenylethyl)acetamide (3n). The general procedure was followed using $0.200 \mathrm{~g}(0.797 \mathrm{mmol})$ of $(R)$-2-azido- $N$-(1-phenylethyl)acetamide (1e), $0.130 \mathrm{~g}(0.980 \mathrm{mmol})$ of (prop-2-yn-1-yloxy)benzene (2e), $10 \mathrm{mg}$ of $\mathrm{Cu}_{2} \mathrm{O} / \mathrm{C}$ and $2.2 \mathrm{~mL}$ of $\mathrm{Et}_{3} \mathrm{~N}$ to give $0.253 \mathrm{~g}(77 \%)$ of $\mathbf{3 n}$ as a white solid. The solid residue was purified by crystallization using (ethyl acetate/diethyl ether). Mp $132-135{ }^{\circ} \mathrm{C}$; IR (film) $v_{\max } / \mathrm{cm}^{-1}: 3287$, 3063, 1669, 1599, 1551, 1494, 1240, 1032, 754; ${ }^{1} \mathrm{H}$ NMR $\left(\mathrm{CDCl}_{3}, 400 \mathrm{MHz}\right) \delta / \mathrm{ppm}: 7.76$ (s, $1 \mathrm{H}), 7.29-7.18(\mathrm{~m}, 7 \mathrm{H}), 6.97-6.93(\mathrm{~m}, 3 \mathrm{H}), 5.14(\mathrm{~s}, 2 \mathrm{H}), 5.03(\mathrm{~m}, 1 \mathrm{H}), 4.94(\mathrm{~m}, 2 \mathrm{H}), 1.40(\mathrm{~d}, 3 \mathrm{H}$, $J 7.2 \mathrm{~Hz}) .{ }^{13} \mathrm{C} \mathrm{NMR}\left(\mathrm{CDCl}_{3}, 100 \mathrm{MHz}\right) \delta / \mathrm{ppm}$ : 164.1, 158.0, 144.6, 142.3, 129.6, 128.7, 127.5, 126.1, 124.6, 121.4, 114.7, 61.8, 52.8, 49.6, 21.7. Anal. Calcd for $\mathrm{C}_{19} \mathrm{H}_{20} \mathrm{~N}_{4} \mathrm{O}_{2} \mathrm{C}, 67.84 ; \mathrm{H}, 5.99$; N, 16.66. Found: C, 67.67; H 5.35; N, 16.78\%.

1,3,5-Tris[(4-phenyl-1H-1,2,3-triazol-yl)methyl]benzene (3o). ${ }^{7 \mathrm{a}, 24}$ The general procedure was followed using $0.10 \mathrm{~g}(1.23 \mathrm{mmol})$ of 1,2,3-tris(azidomethyl)benzene (1f), $0.134 \mathrm{~mL}(1.23$ mmol) of phenylacetylene (2a), $5 \mathrm{mg}$ of $\mathrm{Cu}_{2} \mathrm{O} / \mathrm{C}$ and $1.1 \mathrm{~mL}$ of $\mathrm{Et}_{3} \mathrm{~N}$ to give $0.120 \mathrm{~g}(79 \%)$ of $\mathbf{3 n}$ as a white solid. The solid residue was purified by flash chromatography using (ethyl acetate/hexane). Mp 221-223 ${ }^{\circ} \mathrm{C}$; IR (film) $v_{\max } / \mathrm{cm}^{-1}: 3076,2938,1430,1353,762 ;{ }^{1} \mathrm{H}$ NMR (DMSO- $\left.d_{6}, 400 \mathrm{MHz}\right) \delta / \mathrm{ppm}: 8.56(\mathrm{~s}, 3 \mathrm{H}), 7.76(\mathrm{~d}, 6 \mathrm{H}, J 7.3 \mathrm{~Hz}), 7.37$ (t, 6H, J 7.3 Hz), 7.29 $(\mathrm{m}, 9 \mathrm{H}), 5.61(\mathrm{~s}, 6 \mathrm{H}) .{ }^{13} \mathrm{C}$ NMR (DMSO- $\left.d_{6}, 100 \mathrm{MHz}\right) \delta / \mathrm{ppm}: 147.2,137.8,131.2,129.4$, $128.5,127.8,125.7,122.0,53.1$.

1-Benzyl-4-[(4-bromophenoxy)methyl]-1H-1,2,3-triazole (3p). The general procedure was followed using $0.20 \mathrm{~g}$ (1.46 mmol) of benzyl azide (1a), $0.308 \mathrm{~g}(1.46 \mathrm{mmol})$ of 1-bromo-4-(pro2-yn-1-yloxy)benzene (2f), $10 \mathrm{mg}$ of $\mathrm{Cu}_{2} \mathrm{O} / \mathrm{C}$ and $2.2 \mathrm{~mL}$ of $\mathrm{Et}_{3} \mathrm{~N}$ to give $0.402 \mathrm{~g}(80 \%)$ of $\mathbf{3 p}$ as a white solid. The solid residue was purified by crystallization using (acetone/diethyl ether). Mp 132-134 ${ }^{\circ} \mathrm{C}$; IR (film) $v_{\max } / \mathrm{cm}^{-1}: 3139,1623,1585,1489,1227,995,619 ;{ }^{1} \mathrm{H} \mathrm{NMR}\left(\mathrm{CDCl}_{3}, 400\right.$

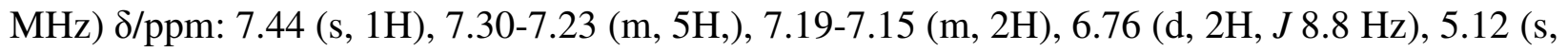
2H), 5.03 (s, 2H). ${ }^{13} \mathrm{C} \mathrm{NMR}\left(\mathrm{CDCl}_{3}, 100 \mathrm{MHz}\right) \delta / \mathrm{ppm}: 157.2,144.1,134.3,132.3,129.1,128.8$, 128.1, 127.7, 122.7, 116.5, 113.4, 62.1, 54.2 Anal. Calcd for $\mathrm{C}_{16} \mathrm{H}_{14} \mathrm{BrN}_{3} \mathrm{O} \mathrm{C}, 55.83 ; \mathrm{H}, 4.10$; N, 12.21. Found: C, 55.84; H, 4.03; N, 11.88\% HRMS (ESI) Calcd for $\mathrm{C}_{16} \mathrm{H}_{14} \mathrm{BrN}_{3} \mathrm{O}\left[(\mathrm{M}+\mathrm{H})^{+}\right]$ 344.0399; Found 344.0393.

1,4-Bis[[4-[(4-bromophenoxy)methyl]-1H-1,2,3-triazol-4-yl]methyl]benzene (3q). The general procedure was followed using $0.20 \mathrm{~g}(1.06 \mathrm{mmol})$ of 1,4-bis(azidomethyl)benzene $(\mathbf{1 c}), 0.45 \mathrm{~g}$ (2.12 mmol) of 1-bromo-4-(pro-2-yn-1-yloxy)benzene (2f), $10 \mathrm{mg}$ of $\mathrm{Cu}_{2} \mathrm{O} / \mathrm{C}$ and $2.2 \mathrm{~mL}$ of $\mathrm{Et}_{3} \mathrm{~N}$ to give $0.564 \mathrm{~g}(87 \%)$ of $\mathbf{3 q}$ as a yellow solid. The solid residue was purified by crystallization using (ethyl acetate/hexane). Mp $177-179^{\circ} \mathrm{C}$; IR (film) $v_{\max } / \mathrm{cm}^{-1}$ : 3074, 1590, 
1489, 1238, 1040, 814, $619 ;{ }^{1} \mathrm{H}$ NMR (DMSO- $d_{6}, 400 \mathrm{MHz}$ ) $\delta / \mathrm{ppm}: 8.23$ (s, 2H), 7.40 (d, 4H, $J$ $8.8 \mathrm{~Hz}), 7.27(\mathrm{~s}, 4 \mathrm{H}), 6.95(\mathrm{~d}, 4 \mathrm{H}, J 9.2 \mathrm{~Hz}), 5.55(\mathrm{~s}, 4 \mathrm{H}), 5.07$ (s, 4H). ${ }^{13} \mathrm{C}$ NMR (DMSO- $d_{6}, 100$

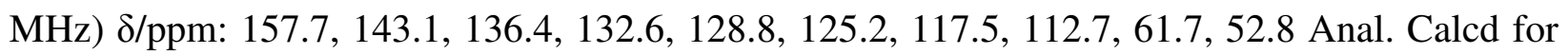
$\mathrm{C}_{26} \mathrm{H}_{22} \mathrm{Br}_{2} \mathrm{~N}_{6} \mathrm{O}_{2} \mathrm{C}, 51.17 ; \mathrm{H}, 3.63 ; \mathrm{N}, 13.77$. Found: C, 51.02; H, 3.60; N, 13.50\%. HRMS (ESI) Calcd for $\mathrm{C}_{26} \mathrm{H}_{22} \mathrm{Br}_{2} \mathrm{~N}_{6} \mathrm{O}_{2}\left[(\mathrm{M}+\mathrm{H})^{+}\right]$609.0250; Found 609.0244.

1,3-Bis[(4-benzyl-1H-1,2,3-triazol-yl)methyl]benzene (3r). The general procedure was followed using $0.50 \mathrm{~g}$ (2.65 mmol) of 1,3-bis(azidomethyl)benzene (1g), $0.58 \mathrm{~mL}$ (5.31 mmol) of phenylacetylene (2a), $25 \mathrm{mg}$ of $\mathrm{Cu}_{2} \mathrm{O} / \mathrm{C}$ and $5.5 \mathrm{~mL}$ of $\mathrm{Et}_{3} \mathrm{~N}$ to give $0.821 \mathrm{~g}(79 \%)$ of $3 \mathbf{r}$ as a white solid. The solid residue was purified by crystallization using ethyl acetate. $\mathrm{Mp} 162-164^{\circ} \mathrm{C}$; IR (film) $v_{\max } / \mathrm{cm}^{-1}: 3130,2919,1609,1432,1221,1074,764 ;{ }^{1} \mathrm{H} \mathrm{NMR}\left(\mathrm{CDCl}_{3}, 400 \mathrm{MHz}\right)$

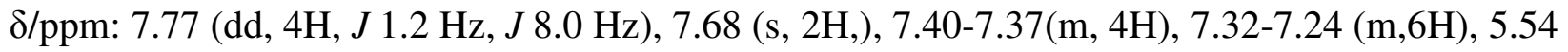
(s, 4H). ${ }^{13} \mathrm{C} \mathrm{NMR}\left(\mathrm{CDCl}_{3}, 100 \mathrm{MHz}\right) \delta / \mathrm{ppm}: 148.3,135.9,130.2,130.0,128.8,128.3,128.2$, 127.3, 125.7, 119.6, 53.8 Anal. Calcd for $\mathrm{C}_{24} \mathrm{H}_{20} \mathrm{~N}_{6} \mathrm{C}$, 73.45; H, 5.14; N, 21.41 Found: C, 73.02; $\mathrm{H}, 5.16$; N, 21.59\%. HRMS (ESI) Calcd for $\mathrm{C}_{24} \mathrm{H}_{20} \mathrm{~N}_{6},\left[(\mathrm{M}+\mathrm{H})^{+}\right] 393.1828$; Found 393.1826.

1,3-Bis[[(4-phenoxymethyl)-1H-1,2,3-triazol-1-yl]methyl]benzene (3s). The general procedure was followed using $0.39 \mathrm{~g}(2.07 \mathrm{mmol})$ of 1,3-bis(azidomethyl)benzene (1g), $0.540 \mathrm{~g}$ (4.14 $\mathrm{mmol}$ ) of (prop-2-yn-1-yloxy)benzene (2e), $19 \mathrm{mg}$ of $\mathrm{Cu}_{2} \mathrm{O} / \mathrm{C}$ and $4.3 \mathrm{~mL}^{\circ} \mathrm{Et}_{3} \mathrm{~N}$ to give 0.739 $\mathrm{g}(80 \%)$ of $\mathbf{3 s}$ as a white solid. The solid residue was purified by crystallization using ethyl acetate. Mp $115-117^{\circ} \mathrm{C}$; IR (film) $v_{\max } / \mathrm{cm}^{-1}: 3140,2924,1601,1498,1247,1030,756 ;{ }^{1} \mathrm{H} \mathrm{NMR}$ $\left(\mathrm{CDCl}_{3}, 400 \mathrm{MHz}\right) \delta / \mathrm{ppm}: 7.54(\mathrm{~s}, 2 \mathrm{H}), 7.34(\mathrm{t}, 1 \mathrm{H}, J 7.6 \mathrm{~Hz}), 7.27-7.15(\mathrm{~m}, 6 \mathrm{H}),, 7.13(\mathrm{~m}, 1 \mathrm{H})$ 6.95-6.92 (m, 6H), $5.47(\mathrm{~s}, 4 \mathrm{H}), 5.15(\mathrm{~s}, 4 \mathrm{H}) .{ }^{13} \mathrm{C} \mathrm{NMR}\left(\mathrm{CDCl}_{3}, 100 \mathrm{MHz}\right) \delta / \mathrm{ppm}: 158.1,144.8$, 135.6, 130.0, 129.5, 128.3, 127.5, 122.8, 121.3, 114.7, 61.9, 53.7 Anal. Calcd for $\mathrm{C}_{26} \mathrm{H}_{24} \mathrm{~N}_{6} \mathrm{O}_{2} \mathrm{C}$, 69.01; H, 5.35; N, 18.57. Found: C, 68.70; H, 5.32; N, 18.43\%. HRMS (ESI) Calcd for $\mathrm{C}_{26} \mathrm{H}_{24} \mathrm{~N}_{6} \mathrm{O}_{2}\left[(\mathrm{M}+\mathrm{H})^{+}\right]$453.2040; Found 453.2034.

5-Chloro-2-(4-phenyl-1H-1,2,3-triazol-1-yl)phenol (3t). The general procedure was followed using $0.375 \mathrm{~g}(2.22 \mathrm{mmol})$ of 2-azido-5-chlorophenol (1h), $0.244 \mathrm{~mL}(2.22 \mathrm{mmol})$ of phenylacetylene (2a), $19 \mathrm{mg}$ of $\mathrm{Cu}_{2} \mathrm{O} / \mathrm{C}$ and $4.12 \mathrm{~mL}$ of $\mathrm{Et}_{3} \mathrm{~N}$ to give $0.480 \mathrm{~g}(80 \%)$ of $\mathbf{3 t}$ as a white solid. The solid residue was purified by flash chromatography using (ethyl acetate/hexane). Mp 276-278 ${ }^{\circ} \mathrm{C}$; IR (film) $v_{\max } / \mathrm{cm}^{-1}: 3452,2919,2850,1601,1438,1235,1060,757 ;{ }^{1} \mathrm{H}$ NMR (DMSO- $\left.d_{6}, 400 \mathrm{MHz}\right) \delta / \mathrm{ppm}: 8.93(\mathrm{~s}, 1 \mathrm{H}), 7.95(\mathrm{~d}, 2 \mathrm{H}, J$ 6.8), 7.67 (d, 1H, J $8 \mathrm{~Hz}), 7.48$ (m, $2 \mathrm{H}), 6.37(\mathrm{~m}, 1 \mathrm{H}), 7.20(\mathrm{~d}, 1 \mathrm{H}, J 2 \mathrm{~Hz}), 7.09(\mathrm{dd}, 1 \mathrm{H}, J 2.4 \mathrm{~Hz}, J 8.4 \mathrm{~Hz}) .{ }^{13} \mathrm{C}$ NMR (DMSO- $d_{6}$, $100 \mathrm{MHz}$ ) $\delta / \mathrm{ppm}: 151.7,146.7,134.5,130.8,129.4$, 128.5, 127.3, 125.7, 124.2, 123.5, 119.7 , 117.1. Anal. Calcd for $\mathrm{C}_{14} \mathrm{H}_{10} \mathrm{ClN}_{3} \mathrm{O}$ C, 61.89; H, 3.71; N, 15.47. Found: C, 61.50; H, 3.66; N, 14.89\%. HRMS (ESI) Calcd for $\mathrm{C}_{14} \mathrm{H}_{10} \mathrm{ClN}_{3} \mathrm{O}\left[(\mathrm{M}+\mathrm{H})^{+}\right] 272.0591$; Found 272.0584.

1,3-Bis[[4-[(4-bromophenoxy)methyl]-1H-1,2,3-triazol-1-yl]methyl]benzene (3u). The general procedure was followed using $0.20 \mathrm{~g}(1.06 \mathrm{mmol})$ of 1,3-bis(azidomethyl)benzene $(\mathbf{1 g}), 0.45 \mathrm{~mL}$ (1.14 mmol) of 1-bromo-4-(prop-2-yn-1-yloxy)benzene (2f), $10 \mathrm{mg}$ of $\mathrm{Cu}_{2} \mathrm{O} / \mathrm{C}$ and $2.2 \mathrm{~mL}$ of $\mathrm{Et}_{3} \mathrm{~N}$ to give $0.580 \mathrm{~g}(90 \%)$ of $\mathbf{3 u}$ as a brown solid. The solid residue was purified by crystallization using dichloromethane. Mp 166-168 ${ }^{\circ} \mathrm{C}$; IR (film) $v_{\max } / \mathrm{cm}^{-1}: 3153,1592,1489$, 1253, 1044, 825; ${ }^{1} \mathrm{H}$ NMR (DMSO-d $6,400 \mathrm{MHz}$ ) $\delta / \mathrm{ppm}: 8.25$ (s, 2H), 7.42 (d, 4H, J 9.2 Hz), 
$7.35(\mathrm{t}, 1 \mathrm{H}, J 7.6 \mathrm{~Hz}), 7.30(\mathrm{~m}, 1 \mathrm{H}), 7.22(\mathrm{dd}, 2 \mathrm{H}, J 1.6 \mathrm{~Hz}, J 7.6 \mathrm{~Hz}), 6.97(\mathrm{~d}, 4 \mathrm{H}, J 9.2 \mathrm{~Hz})$, 5.57 (s, 4H), 5.09 (s, 4H). ${ }^{13} \mathrm{C}$ NMR (DMSO-d, $\left.100 \mathrm{MHz}\right) \delta / \mathrm{ppm}: 157.7,143.1,137.0,132.5$, 129.8, 128.2, 128.0, 125.3, 117.5, 112.7, 61.7, 53.0. Anal. Calcd for $\mathrm{C}_{26} \mathrm{H}_{22} \mathrm{Br}_{2} \mathrm{~N}_{6} \mathrm{O}_{2} \mathrm{C}, 51.17 ; \mathrm{H}$, 3.63; N, 13.77. Found: C, 51.13; H, 3.46; N, 13.01\%. HRMS (ESI) Calcd for $\mathrm{C}_{26} \mathrm{H}_{22} \mathrm{Br}_{2} \mathrm{~N}_{6} \mathrm{O}_{2}$ $\left[(\mathrm{M}+\mathrm{H})^{+}\right]$609.0250; Found 609.0239.

2-(1-Benzyl-1H-1,2,3-triazol-1-yl)pyridine (3v). The general procedure was followed using $0.10 \mathrm{~g}(0.734 \mathrm{mmol})$ of benzyl azide $(\mathbf{1 a}), 0.073 \mathrm{~mL}(0.734 \mathrm{mmol})$ of 2-ethynylpyridine $(\mathbf{2 g}), 5$ $\mathrm{mg}$ of $\mathrm{Cu}_{2} \mathrm{O} / \mathrm{C}$ and $1.1 \mathrm{~mL}$ of $\mathrm{Et}_{3} \mathrm{~N}$ to give $0.130 \mathrm{~g}(78 \%)$ of $\mathbf{3 v}$ as a white solid. The solid residue was purified by crystallization using (ethyl acetate/hexane). Mp $118-120{ }^{\circ} \mathrm{C}$; IR (film) $v_{\max } / \mathrm{cm}^{-1}: 3106,1595,1421,1224,1045,786,727 ;{ }^{1} \mathrm{H} \mathrm{NMR}\left(\mathrm{CDCl}_{3}, 400 \mathrm{MHz}\right) \delta / \mathrm{ppm}: 8.50$ (m, 1H), $8.14(\mathrm{dd}, 1 \mathrm{H}, J 1.2 \mathrm{~Hz}, J 8.4 \mathrm{~Hz}), 8.02(\mathrm{~s}, 1 \mathrm{H}), 7.37$ (td, 1H, J 2.4 Hz, J 8.4 Hz), 7.35-

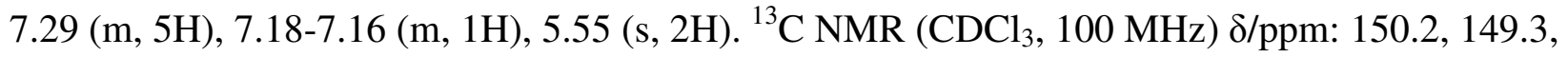
148.7, 136.9, 134.3, 129.1, 128.8, 128.3, 122.8, 121.9, 120.2, 54.3. Anal. Calcd for $\mathrm{C}_{14} \mathrm{H}_{12} \mathrm{~N}_{4} \mathrm{C}$, 71.17; H, 5.12; N, 23.71. Found: C, 70.93; H, 5.13; N, 23.78\%. HRMS (ESI) Calcd for $\mathrm{C}_{14} \mathrm{H}_{12} \mathrm{~N}_{4}$ $\left[(\mathrm{M}+\mathrm{H})^{+}\right]$237.1141; Found 237.1136.

1,3,5-Tris[(1-benzyl-1H-1,2,3-triazol-4-yl)methyloxy]benzene (3w). The general procedure was followed using $0.20 \mathrm{~g}$ (1.46 mmol) of benzyl azide (1a), $0.117 \mathrm{~g}(0.489 \mathrm{mmol})$ of 1,3,5tris(prop-2-ynyloxy)benzene (2h), $10 \mathrm{mg}$ of $\mathrm{Cu}_{2} \mathrm{O} / \mathrm{C}$ and $2.2 \mathrm{~mL}$ of $\mathrm{Et}_{3} \mathrm{~N}$ to give $0.130 \mathrm{~g}(78 \%)$ of $\mathbf{3 w}$ as a white solid. The solid residue was purified by crystallization using (ethyl acetate/hexane). Mp 144-146 ${ }^{\circ} \mathrm{C}$; IR (film) $v_{\max } / \mathrm{cm}^{-1}$ : 3141, 1610, 1457, 1153, 1051, 804, 720 ; ${ }^{1} \mathrm{H}$ NMR (DMSO- $\left.d_{6}, 400 \mathrm{MHz}\right) \delta / \mathrm{ppm}: 8.24(\mathrm{~s}, 3 \mathrm{H}), 7.33-7.26(\mathrm{~m}, 15 \mathrm{H}), 6.27(\mathrm{~s}, 3 \mathrm{H}), 7.57$ (s, $6 \mathrm{H}), 5.03(\mathrm{~s}, 6 \mathrm{H}) .{ }^{13} \mathrm{C}$ NMR (DMSO-d, $\left.100 \mathrm{MHz}\right) \delta / \mathrm{ppm}: 160.2,143.3,136.4,129.2,128.6$, 128.4, 125.2, 94.9, 61.5, 53.3. Anal. Calcd for $\mathrm{C}_{36} \mathrm{H}_{33} \mathrm{~N}_{9} \mathrm{O}_{3} \mathrm{C}$, 67.59; H, 5.20; N, 19.71. Found: C, 67.36; H, $5.07 \mathrm{~N}, 19.62 \%$. HRMS (ESI) Calcd for $\mathrm{C}_{36} \mathrm{H}_{33} \mathrm{~N}_{9} \mathrm{O}_{3}\left[(\mathrm{M}+\mathrm{H})^{+}\right], 640.2785$; Found 640.2778 .

2-[2-[(1-Benzyl-1H-1,2,3-triazol-4-yl)methoxy]phenyl]-5-methylbenzoxazole (9a). The general procedure was followed using $0.1 \mathrm{~g}(0.73 \mathrm{mmol})$ of benzyl azide $(\mathbf{1 a}), 0.20 \mathrm{~g}(0.76 \mathrm{mmol})$ of 5methyl-2-(2-prop-2-yn-1-yloxy)phenyl)benzoxazole (8a), $10 \mathrm{mg}$ of $\mathrm{Cu}_{2} \mathrm{O} / \mathrm{C}$ and $2.2 \mathrm{~mL}$ of $\mathrm{Et}_{3} \mathrm{~N}$ to give $0.26 \mathrm{~g}(87 \%)$ of $9 \mathbf{a}$ as a white solid. The solid residue was purified by flash chromatography using (ethyl acetate/hexane). Mp. 179-180 ${ }^{\circ} \mathrm{C}$. IR (film) $v_{\max } / \mathrm{cm}^{-1}: 3412,2346$,

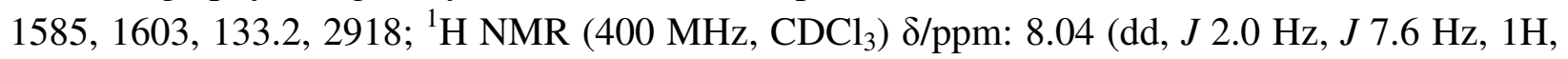
2H), $7.74(\mathrm{~s}, 1 \mathrm{H}), 7.40$ (ddd, J $2.0 \mathrm{~Hz}, J 7.6 \mathrm{~Hz}, J 8.4 \mathrm{~Hz}, 1 \mathrm{H}), 7.32(\mathrm{~m}, 1 \mathrm{H}), 7.30(\mathrm{~m}, 3 \mathrm{H}), 7.21$ $(\mathrm{m}, 2 \mathrm{H}), 7.40(\mathrm{~d}, J 8.4 \mathrm{~Hz}, 1 \mathrm{H}), 7.10(\mathrm{~d}, J 8.0 \mathrm{~Hz}, 1 \mathrm{H}), 7.03(\mathrm{~m}, 2 \mathrm{H}), 5.46(\mathrm{~s}, 2 \mathrm{H}), 5.32(\mathrm{~s}, 2 \mathrm{H})$, $2.41(\mathrm{~s}, 3 \mathrm{H}) .{ }^{13} \mathrm{C} \mathrm{NMR}\left(100 \mathrm{MHz}, \mathrm{CDCl}_{3}\right) \delta / \mathrm{ppm}: 161.6,156.9,148.6,145.2,142.2,134.6$, 134.0, 132.7, 131.2, 129.2, 128.8, 128.1, 126.1, 122.8, 121.5, 119.8, 116.9, 114.0, 109.7, 63.9, 54.3, 21.5. Anal. Calcd for $\mathrm{C}_{24} \mathrm{H}_{20} \mathrm{~N}_{4} \mathrm{O}_{2} \mathrm{C}, 72.71 ; \mathrm{H}, 5.08 ; \mathrm{N}, 14.13$. Found: C, 72.43; H, 5.09; N, $14.16 \%$.

2-[2-[(1-Benzyl-1H-1,2,3-triazol-4-yl)methoxyl]phenyl]-6-chlorobenzoxazole (9b). The general procedure was followed using $0.10 \mathrm{~g}(0.73 \mathrm{mmol})$ of benzyl azide $(\mathbf{1 a}), 0.20 \mathrm{~g}(0.73 \mathrm{mmol})$ of 6- 
chloro-2-(2-prop-2-yn-1-yloxy)phenyl)benzoxazole $(\mathbf{8 b}), 10 \mathrm{mg}$ of $\mathrm{Cu}_{2} \mathrm{O} / \mathrm{C}$ and $2.2 \mathrm{~mL}$ of $\mathrm{Et}_{3} \mathrm{~N}$ to give $0.22 \mathrm{~g}(75 \%)$ of $\mathbf{9 b}$ as a white solid. The solid residue was purified by crystallization using (ethyl acetate/hexane). Mp. $171-172^{\circ} \mathrm{C}$. IR (film) $v_{\max } / \mathrm{cm}^{-1}: 763,3453,2346,1452,1598$, 133.2, 2920; ${ }^{1} \mathrm{H}$ NMR (400 MHz, $\mathrm{CDCl}_{3}$ ) $\delta / \mathrm{ppm}: 8.07$ (dd, J $\left.1.7 \mathrm{~Hz}, J 7.8 \mathrm{~Hz}, 1 \mathrm{H}\right), 7.74(\mathrm{~s}, 1 \mathrm{H})$, 7.47 (ddd, J 1.7 Hz, J 7.3 Hz, 1H), 7.47 (d, J 8.4 Hz, 1H), 7.39 (d, J 1.8 Hz, 1H), 7.36 (m, 3H), $7.27(\mathrm{~m}, 3 \mathrm{H}), 7.17(\mathrm{dd}, J 0.7 \mathrm{~Hz}, J 8.4 \mathrm{~Hz}, 1 \mathrm{H}), 7.09$ (td, J $1.0 \mathrm{~Hz}, J 7.7 \mathrm{~Hz}, 1 \mathrm{H}), 5.53$ (s, 2H), 5.37 (s, 2H). ${ }^{13} \mathrm{C}$ NMR (100 MHz, $\left.\mathrm{CDCl}_{3}\right) \delta / \mathrm{ppm}$ : 162.2, 157.0, 150.5, 144.9, 140.7, 134.4, 133.2 , 131.3, 130.5, 129.2, 128.9, 128.2, 125.0, 122.7, 121.5, 120.4, 116.2, 113.9, 110.9, 63.8, 54.3. Anal. Calcd for $\mathrm{C}_{23} \mathrm{H}_{17} \mathrm{ClN}_{4} \mathrm{O}_{2} \mathrm{C}, 66.27 ; \mathrm{H}, 4.11 ; \mathrm{N}, 13.44$. Found: C, 66.25; H, 4.02; N, $13.47 \%$.

2-[2-[(1-Benzyl-1H-1,2,3-triazol-4-yl)methoxy]phenyl]-5-chloro-6-nitrobenzoxazole (9c). The general procedure was followed using $0.08 \mathrm{~g}(0.61 \mathrm{mmol})$ of benzyl azide (1a), $0.20 \mathrm{~g}(0.61$ $\mathrm{mmol}$ ) of 5-chloro-6-nitro-2-(2-prop-2-ynyloxy)phenyl)benzoxazole (8c), $10 \mathrm{mg}$ of $\mathrm{Cu}_{2} \mathrm{O} / \mathrm{C}$ and $2.2 \mathrm{~mL}$ of $\mathrm{Et}_{3} \mathrm{~N}$ to give $0.23 \mathrm{~g}(82 \%)$ of $9 \mathrm{c}$ as a yellow solid. The solid residue was purified by crystallization using (ethyl acetate/hexane). Mp. $188-189^{\circ} \mathrm{C} .{ }^{1} \mathrm{H}$ NMR $\left(400 \mathrm{MHz}, \mathrm{CDCl}_{3}\right) \delta / \mathrm{ppm}$ : 8.07 (dd, J 2.0 Hz, J 8.0 Hz, 1H), 7.89 (s, 1H), 7.67 (s, 1H), 7.60 (s, 1H), 7.5 (ddd, J 1.6 Hz, J $7.2 \mathrm{~Hz}, J 8.8 \mathrm{~Hz}, 1 \mathrm{H}), 7.34-7.31(\mathrm{~m}, 3 \mathrm{H}), 7.23$ (dd, J $2.8 \mathrm{~Hz}, J 7.6 \mathrm{~Hz}, 2 \mathrm{H}), 7.18$ (d, J 7.6 Hz, 1H), $7.07(\mathrm{td}, J 1.0 \mathrm{~Hz}, J 7.6 \mathrm{~Hz}, J 8.4 \mathrm{~Hz}, 1 \mathrm{H}), 5.50(\mathrm{~s}, 1 \mathrm{H}), 5.33(\mathrm{~s}, 1 \mathrm{H}) .{ }^{13} \mathrm{C} \mathrm{NMR}(100 \mathrm{MHz}$, $\mathrm{CDCl}_{3}$ ) $\delta / \mathrm{ppm}: 166.5,157.6,147.7,145.8,144.4,134.5,134.3,131.7,129.3,129.1,128.2$, 123.4, 122.6, 122.0, 121.6, 114.9, 113.9, 108.4, 63.6, 54.4. Anal. Calcd for $\mathrm{C}_{23} \mathrm{H}_{16} \mathrm{ClN}_{5} \mathrm{O}_{4}$; $\mathrm{C}$, 59.81; H, 3.49; N, 15.16. Found: C, 59.58; H, 3.29; N, 14.88\%.

2-[2-[(1-Benzyl-1H-1,2,3-triazol-4-yl)methoxy]-5-bromophenyl]-5-methylbenzoxazole (9d). The general procedure was followed using $0.079 \mathrm{~g}(0.58 \mathrm{mmol})$ of benzyl azide $(\mathbf{1 a}), 0.20 \mathrm{~g}$ (0.58 mmol) of 2-(5-bromo-2-(prop-2-ynyloxy)phenyl)-5-methylbenzoxazole (8d), $10 \mathrm{mg}$ of $\mathrm{Cu}_{2} \mathrm{O} / \mathrm{C}$ and $2.2 \mathrm{~mL}$ of $\mathrm{Et}_{3} \mathrm{~N}$ to give $0.22 \mathrm{~g}(80 \%)$ of $9 \mathbf{d}$ as a white solid The solid residue was purified by flash chromatography using (ethyl acetate/hexane). Mp. 193-195 ${ }^{\circ} \mathrm{C}$. IR (film) $v_{\max } / \mathrm{cm}^{-1}: 757,3440,2345,1594,1592,1033,2919.3 .{ }^{1} \mathrm{H}$ NMR $\left(400 \mathrm{MHz}, \mathrm{CDCl}_{3}\right) \delta / \mathrm{ppm}: 8.16$ $(\mathrm{s}, 1 \mathrm{H}), 7.71(\mathrm{~s}, 1 \mathrm{H}), 7.46(\mathrm{~d}, J 8 \mathrm{~Hz}, 1 \mathrm{H}), 7.34-7.30(\mathrm{~m}, 4 \mathrm{H}), 7.14-7.21(\mathrm{~m}, 3 \mathrm{H}), 7.05(\mathrm{~d}, J 8 \mathrm{~Hz}$, $1 \mathrm{H}), 7.01(\mathrm{~d}, J 8 \mathrm{~Hz}, 1 \mathrm{H}), 5.46(\mathrm{~s}, 2 \mathrm{H}), 5.29(\mathrm{~s}, 2 \mathrm{H}), 2.41(\mathrm{~s}, 3 \mathrm{H}) .{ }^{13} \mathrm{C} \mathrm{NMR}\left(100 \mathrm{MHz}, \mathrm{CDCl}_{3}\right)$

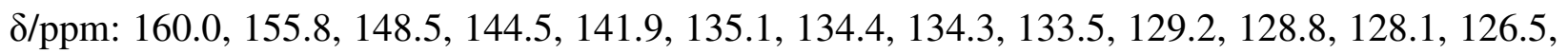
122.8, 119.9, 118.6, 115.8, 113.7, 109.7, 64.0, 54.31, 21.5. Anal. Calcd for $\mathrm{C}_{24} \mathrm{H}_{19} \mathrm{BrN}_{4} \mathrm{O}_{2}$; C, $60.64 ; \mathrm{H}, 4.04 ; \mathrm{N}, 11.79$. Found: C, 60.66; H, 3.64; N, $11.56 \%$.

2-[2-[(1-Benzyl-1H-1,2,3-triazol-4-yl)methyloxy]-5-bromophenyl]benzoxazole (9e). The general procedure was followed using $0.09 \mathrm{~g}(0.66 \mathrm{mmol})$ of benzyl azide (1a), $0.200 \mathrm{~g}(0.61$ $\mathrm{mmol}$ ) of 2-(5-bromo-2-(prop-2-yn-1-yloxy)phenyl)benzoxazole $(\mathbf{8 e}), 10 \mathrm{mg}$ of $\mathrm{Cu}_{2} \mathrm{O} / \mathrm{C}$ and 2.2 $\mathrm{mL}$ of $\mathrm{Et}_{3} \mathrm{~N}$ to give $0.25 \mathrm{~g}(89 \%)$ of $9 \mathrm{e}$ as a white solid. The solid residue was purified by crystallization using (ethyl acetate/hexane). Mp. $179-180^{\circ} \mathrm{C}$. IR (film) $v_{\max } / \mathrm{cm}^{-1}$ : IR (film)

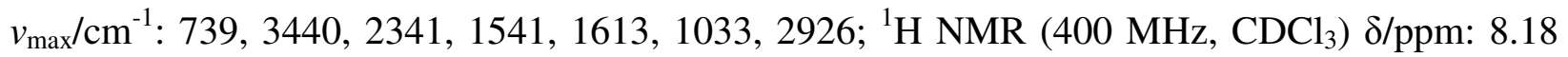
$(\mathrm{d}, J 2.0 \mathrm{~Hz}, 1 \mathrm{H}), 7.70$ (s, 1H), 7.56 (ddd, J $0.6 \mathrm{~Hz}, J 3.0 \mathrm{~Hz}, J 7.5 \mathrm{~Hz}, 1 \mathrm{H}), 7.48$ (dd, $J 2.5 \mathrm{~Hz}, J$ $8.8 \mathrm{~Hz}, 1 \mathrm{H}), 7.27(\mathrm{~m}, 6 \mathrm{H}), 7.20(\mathrm{~m}, 2 \mathrm{H}), 7.03(\mathrm{~d}, J 8.9 \mathrm{~Hz}, 1 \mathrm{H}), 5.46(\mathrm{~s}, 2 \mathrm{H}), 5.30(\mathrm{~s}, 2 \mathrm{H}) .{ }^{13} \mathrm{C}$ 
NMR (100 MHz, $\mathrm{CDCl}_{3}$ ) $\delta / \mathrm{ppm}: 160.0,156.0,150.3,144.5,141.7,135.3,134.4,133.6,129.2$, $128.9,128.2,125.4,124.5,122.9,120.1,118.5,116.0,113.8,110.4,64.0,54.3$. Anal. Calcd for $\mathrm{C}_{23} \mathrm{H}_{17} \mathrm{BrN}_{4} \mathrm{O}_{2} ; \mathrm{C}, 59.88 ; \mathrm{H}, 3.71 ; \mathrm{N}, 12.15$. Found: C, 59.86; H, 3.78; N, $11.98 \%$.

\section{Acknowledgements}

We are indebted to Dr. Joseph M. Muchowski for friendly, helpful discussions and to CONACyT for financial support (grant CB-2009-01-135172), PROMEP (Síntesis Química y Supramolecular-project-2012) and Dr. José Antonio Rodríguez-Ávila for determination of copper content in the catalyst.

\section{References}

1. (a) Huisgen, R. 1,3-Dipolar Cycloaddition Chemistry; Padwa, A., Ed.; Wiley: New York, 1984.

(b) Kolb, H. C.; Finn, M. G.; Sharpless, K. B. Angew. Chem., Int. Ed. 2001, 40, 2004-2021. http://dx.doi.org/10.1002/1521-3773(20010601)40:11<2004::AID-ANIE2004>3.3.CO;2-X

(c) Rostovtsev, V. V.; Green, L. G.; Fokin, V. V.; Sharpless, K. B. Angew. Chem., Int. Ed. 2002, 41, 2596-2599.

http://dx.doi.org/10.1002/1521-3773(20020715)41:14<2596::AID-ANIE2596>3.0.CO;2-4

(d) Kelly, A. R.; Wei, J.; Kesavan, S.; Marié, J.-C.; Windmon, N.; Young, D. W.; Marcaurelle, L. A. Org. Lett. 2009, 11, 2257-2260.

http://dx.doi.org/10.1021/o1900562u; PMid:19473044 PMCid:2702139.

(e) Tornøe, C. W.; Christensen, C.; Meldal, M. J. Org. Chem. 2002, 67, 3057- 3064. http://dx.doi.org/10.1021/jo011148j

2. (a) Lewis, W. G.; Green, L. G.; Grynszpan, F.; Radiæ, Z.; Carlier, P. R.; Taylor, P.; Finn, M.

G.; Sharpless, K. B. Angew. Chem., Int. Ed. 2002, 41, 1053-1057.

(b) Tron, G. C.; Pirali, T.; Billington, R. A.; Canonico, P. L.; Sorba, G.; Genazzani, A. A. Med. Res. Rev. 2008, 28, 278-308.

http://dx.doi.org/10.1002/med.20107; PMid:17763363.

(c) Lee, T.; Cho, M.; Ko, S.-Y.; Youn, H.-J.; Baek, D. J.; Cho, W.-J.; Kang, C.-Y.; Kim, S. J. Med. Chem. 2007, 50, 585-589.

http://dx.doi.org/10.1021/jm061243q; PMid:17266209.

(d) Maurya, S. K.; Gollapalli, D. R.; Kirubakaran, S.; Zhang, M.; Johnson, C. R.; Benjamin, N. N.; Hedstrom, L.; Cuny, G. D. J. Med. Chem. 2009, 52, 4623-4630. http://dx.doi.org/10.1021/jm900410u; PMid:19624136 PMCid:2810100.

(e) Kold, H. C.; Sharpless, K. B. Drug Discovery Today 2003, 8, 1128-1137. 
(f) Puig-Basagoiti, F.; Qing, M.; Dong, H.; Zhang, B.; Zou, G.; Yuan, Z.; Shi, P.-Y. Antiviral Res. 2009, 83, 71-79. http://dx.doi.org/10.1016/j.antiviral.2009.03.005; PMid:19501258 PMCid:3214651.

(g) Guezguez, R.; Bougrin, K.; Akri, K. E.; Benhida, R. Tetrahedron Lett. 2006, 47, 48074811. http://dx.doi.org/10.1016/j.tetlet.2006.05.050

3. (a) Huisgen, R.; Knorr, R.; Moebius, L.; Szeimies, G. Chem. Ber. 1965, 98, 4014-4021. http://dx.doi.org/10.1002/cber.19650981228

(b) Huisgen, R. Pure Appl. Chem. 1989, 61, 613-628. http://dx.doi.org/10.1351/pac198961040613

4. (a) Kwok, A. W.; Fotsing, J. R.; Fraser, R. J.; Rodionov, V. O.; Fokin, V. V. Org. Lett. 2010, 12, 4217-4219.

(b) Zhang, L.; Chen, X.; Xue, P.; Sun, H. H. Y.; Williams, L. D.; Sharples, K. B.; Fokin, V. V.; Jia, G. J. Am. Chem. Soc. 2005, 127, 15998- 15999. http://dx.doi.org/10.1021/ja054114s; PMid:16287266.

5. For recent reviews, see: (a) Bock, V. D.; Hiemstra, H.; van Maarseveen, J. H. Eur. J. Org. Chem. 2006, 54-68.

(b) Moses, H. E.; Moorhouse, A. D. Chem. Soc. Rev. 2007, 36, 1249-1262. http://dx.doi.org/10.1039/b613014n; PMid:17619685.

(c) Melda, M.; Tornøe, C. W. Chem. Rev. 2008, 108, 2952-3015. http://dx.doi.org/10.1021/cr0783479; PMid:18698735.

6. (a) Diez-González, S.; Correa, A.; Cavallo, L.; Nolan, S. P. Chem, Eur. J. 2006, 12, 75587564. http://dx.doi.org/10.1002/chem.200600961; PMid:16969776.

(b) Broggi, J.; Díez-González, S.; Petersen, J. L.; Berteina-Raboin, S.; Nolan, S. P.; Agrofolio, L. A. Synthesis 2008, 141-148.

7. (a) Chan, T. R.; Hilgraf, R.; Sharpless, K. B.; Fokin, V. V. Org. Lett. 2004, 6, 2853-2855. PMid:15330631.

(b) Gerard, B.; Ryan, J.; Beeler, A. B.; Porco, J. A. Jr. Tetrahedron 2006, 62, 6405-6411. http://dx.doi.org/10.1016/j.tet.2006.04.025

8. (a) Lipshutz, B. H.; Taft, B. R. A. Angew. Chem., Int. Ed. 2006, 45, 8235-8238.

(b) Lipshutz, B. Frieman, B. A.; Tomaso, A. E. Jr. Angew. Chem., Int. Ed. 2006, 45, 12591264.

http://dx.doi.org/10.1002/anie.200503149; PMid:16425315.

(c) Sharghi, H.; Khalifeh, R.; Doroodmand, M. M. Adv. Synth. Catal. 2009, 351, 207-212.

(d) Alonso, F.; Moglie, Y.; Radivoy, G.; Yus, M. Adv. Synth. Catal. 2010, 352, 3208-3214. http://dx.doi.org/10.1002/adsc.201000637

(e) Lee, C.-T.; Hung, S.; Lipshutz, B. H. Adv. Synth. Catal. 2009, 351, 3139-3142.

http://dx.doi.org/10.1002/adsc.200900604

(f) Fuch, M.; Goessler, W.; Pilger, C.; Kappe, C. O. Adv. Synth. Catal. 2010, 352, 323-228. 
(g) Alonso, F.; Moglie, Y.; Radivoy, G.; Yus, M. Org. Biomol. Chem. 2011, 9, 6385-6395. http://dx.doi.org/10.1039/c1ob05735a; PMid:21789331.

9. (a) Bénéteau, V.; Olmos, A.; Boningari, T.; Sommer, J.; Pale, P. Tetrahedron Lett. 2010, 51, 3673-3677.

(b) Alix, A.; Chassaing, S.; Pale, P.; Sommer, J. Tetrahedron 2008, 64, 8922-8929. http://dx.doi.org/10.1016/j.tet.2008.06.086

10. (a) Alonso, F., Moglie, Y.; Radivoy, G.; Yus, M. Tetrahedron Lett. 2009, 50, 2358-2362. http://dx.doi.org/10.1016/j.tetlet.2009.02.220

(b) Alonso, F.; Moglie, Y.; Radivoy, G.; Yus, M. Eur. J. Org. Chem. 2010, 1875-1884. http://dx.doi.org/10.1016/j.tetlet.2005.02.127

(c) Durán-Pachón, L; van Maarseveen, J. H.; Rothenberg, G. Adv. Synth. Catal. 2005, 347, 811-815.

(d) Orgueira, H. A.; Fokas, D.; Isome, Y.; Chan, P. C.-M.; Baldino, C. M. Tetrahedron Lett. 2005, 46, 2911-2914.

http://dx.doi.org/10.1016/j.tetlet.2005.02.127

(e) García-Muñoz, A.; González, J, Trujillo-Reyes, J.; Morales-Luckie, R. A.; SánchezMendieta, V.; González, C.; Fuentes, A.; Cuevas-Yañez, E. Lett. Org. Chem. 2012, 9, 160164.

(f) Kantam, M. L.; Jaya, V. S.; Sreedhar, B.; Mohan Rao, M. M.; Choudary, B. M. J. Mol. Catal. A: Chemical 2006, 256, 273-277.

http://dx.doi.org/10.1016/j.molcata.2006.04.054

11. (a) Song, S.; Rao, R.; Yang, H.; Zhang, A. J. Phys. Chem. C, 2010, 114, 13998-14003.

(b) Orel, Z. C.; Anzlovar, A.; Drazic, G.; Zigon, M. Crystal Growth \& Design, 2007, 7, 453458.

http://dx.doi.org/10.1021/cg060615t

(c) Liu, H.; Miao, W.; Yang, S.; Zhang, Z.; Chen, J. Crystal Growth \& Design, 2009, 9, 1733-1740.

http://dx.doi.org/10.1021/cg800703n

12. Klug, H. P.; Alexander, L. E. X-Ray Diffraction Procedures for Polycrystalline and Amorphous Materials, John Wiley and Sons, 1974, pp. 643.

13. De Jongh, P. E.; Vanmaekelbergh, D.; Kelly, J. Chem. Commun. 1999, 1069-1070. http://dx.doi.org/10.1039/a901232j

14. Shao, C.; Zhu, R.; Luo, S.; Zhang, Q.; Wang, X.; Hu, Y. Tetrahedron Lett. 2011, 52, 37823785.

http://dx.doi.org/10.1016/j.tetlet.2011.05.061

15. Suzuka, T.; Ooshiro, K.; Kina, K. Heterocycles 2010, 81, 601-610. http://dx.doi.org/10.3987/COM-09-11872

16. Chowdhury, C.; Sasmal, A. K.; Dutta, P. K. Tetrahedron Lett. 2009, 50, 2678-2681. http://dx.doi.org/10.1016/j.tetlet.2009.03.120 
17. (a)Yamaguchi, K.; Oishi, T.; Katayama, T.; Mizuno, N. Chem. Eur. J. 2009, 15, 1046410472.

(b) Jin, T.; Yan, M.; Menggenbateer; Minato, T. Bao, M.; Yamamoto, Y. Adv. Synth. Catal. 2011, 353, 3095-3100.

http://dx.doi.org/10.1002/adsc.201100760

(c) Megia-Fernández, A.; Ortega-Muñoz, M.; López-Jaramillo, J.; Hernández-Mateo, F.; Santoyo-Gonzaleza, F. Adv. Synth. Catal. 2010, 352, 3306-3320.

(d) Duran-Panchón, L.; van Maarseven, J. H.; Rothenberg, G. Adv. Synth. Catal. 2005, 347, 811-815.

(e) Park, I. S.; Kwon, M. S.; Kim, Y.; Lee, J. S.; Park, J. Org. Lett. 2008, 10, 497-500. http://dx.doi.org/10.1021/ol702790w; PMid:18181635.

(f) Rejander Reddy, K.; Rajgopal, K.; Kantam, M. L. Catal. Lett. 2007, 114, 36-40.

(g) Chassaing, S.; Kummarraja, M.; Sido, A. S. S.; Pale, P.; Sommer, J. Org. Lett, 2007, 9, 883-886.

http://dx.doi.org/10.1021/ol0631152; PMid:17286410.

(h) Chassaing, S.; Sido, A. S. S.; Alix, A.; Kumarraja, M.; Pale, P.; Sommer, J. Chem. Eur. J. 2008, 14, 6713-6721.

http://dx.doi.org/10.1002/chem.200800479; PMid:18576412.

(i) Namitharan, K.; Kumarraja, M.; Pitchumani, K. Chem. Eur. J. 2009, 15, 2755-2758.

(j) Katayama, K.; Kamata, K.; Yamaguchi, K.; Mizumo, N. ChemSusChem 2009, 2, 59-62.

http://dx.doi.org/10.1002/cssc.200800202; PMid:19132695.

18. Crystallographic data (excluding structure factors) for the structures in this paper has been deposited with the Cambridge Crystallographic Data Centre as a Supplementary Publication Numbers, CCDC 887985 No. for 3c, CCDC 887987 No. for 3l, CCDC 887986 No. for 3p and CCDC 887989 No. for 3v Copy of the data can be obtained, free of charge, on application to CCDC, 12 Union Road, Cambridge CB2 1EZ, UK [fax: +44(0) 1223336033 or e-mail: deposit@ccdc.cam.ac.uk].

19. López-Ruiz, H.; Briseño-Ortega, H.; Rojas-Lima, S.; Santillan, R.; Farfán, N. Tetrahedron Lett. 2011, 52, 4308-4312.

http://dx.doi.org/10.1016/j.tetlet.2011.06.039

20. Crystallographic data (excluding structure factors) for the structures in this paper has been deposited with the Cambridge Crystallographic Data Centre as a Supplementary Publication Numbers, CCDC 887990 No. for 9d.

21. Wang, Y.; Liu, J.; Xia, C. Adv. Synth. Catal. 2011, 353, 1534-1542.

http://dx.doi.org/10.1002/adsc.201000868

22. Hein, J. E.; Fokin, V. V. Chem. Soc. Rev. 2010, 39, 1302-1315. http://dx.doi.org/10.1039/b904091a; PMid:20309487 PMCid:3073167.

23. (a) Shao, C.; Wang, X.; Xu, J.; Zhao, J.; Zhang, Q.; Hu, Y. J. Org. Chem. 2010, 75, 70027005 . 
(b) Jlalia, I.; Elamari, H.; Meganem, F.; Herscovici, J.; Girard, C. Tetrahedron Lett. 2008, 49, 6756-6758.

http://dx.doi.org/10.1016/j.tetlet.2008.09.031

(c) Li, P.; Wang, L.; Zhang, Y. Tetrahedron 2008, 64, 10825-10830.

http://dx.doi.org/10.1016/j.tet.2008.09.021

(d) Díez-González, S.; Nolan, S. P. Angew. Chem. Int. Ed. 2008, 47, 8881-8884.

24. (a) Feldman, A.; Colasson, B. Fokin, V. V. Org. Lett. 2004, 6, 3897-3899. http://dx.doi.org/10.1021/ol048859z; PMid:15496058.

(b) López-Ruiz, H.; Cortés-Hernández, M.; Rojas-Lima, S.; Höpfl, H. J. Mex. Chem. Soc. 2011, 55, 168-175.

25. Orgueira, H. A.; Fokas, D.; Isome, Y.; Chan, P.; Baldino, C. Tetrahedron Lett. 2005, 46, 2911-2914.

http://dx.doi.org/10.1016/j.tetlet.2005.02.127 